\title{
Effect of Inhibitor Concentration and Immersion Time on the Corrosion Rate and Inhibition Efficiency of AISI 1019 Steel in Inhibited Seawater Environment
}

\author{
Emmanuel Iyeni*, Cornelius Oghenetega Obemure \\ Department of Mechanical Engineering, University of Benin, Benin, Nigeria \\ Email address: \\ Iyeni4christ@gmail.com (E. Iyeni), obemurecornelius@gmail.com (C. O. Obemure) \\ ${ }^{*}$ Corresponding author
}

To cite this article:

Emmanuel Iyeni, Cornelius Oghenetega Obemure. Effect of Inhibitor Concentration and Immersion Time on the Corrosion Rate and Inhibition Efficiency of AISI 1019 Steel in Inhibited Seawater Environment. American Journal of Mechanical and Materials Engineering. Vol. 4, No. 3, 2020, pp. 66-80. doi: 10.11648/j.ajmme.20200403.15

Received: January 19, 2020; Accepted: September 17, 2020; Published: September 25, 2020

\begin{abstract}
The effect of inhibitor concentration and immersion time on the corrosion rate and inhibition efficiency of AISI 1019 steel in seawater environment were investigated by means of weight loss measurement (WLM) at an interval of 6days for a period of 60 days. AISI 1019 steel were immersed in seawater solution in the absence and presence of varying inhibitor concentrations of potassium chromate (PC), Sodium Nitrite (SN), Methyl Orange (MO), Methyl Red (MR), Terminalia Catappa Leaves (TCL) Extract, Carica papaya Leaves (CPL) Extract. The results showed that there is an increase in inhibition efficiency with increase in inhibitor concentration and decrease in inhibition efficiency with increase in immersion time. The inorganic inhibitor (potassium chromate), inorganic inhibitor (Sodium Nitrite), the organic Inhibitor (Methyl Orange), the organic inhibitor (Methyl Red), the green inhibitor (Terminalia Catappa Leaves) and green inhibitor (Carica Papaya Leaves) produced their best inhibition efficiency of $71.94 \%, 634 \%, 68.94 \%, 68.32 \%, 62.7 \%, 59.79 \%$ respectively at a concentration of $10 \mathrm{~g} / \mathrm{L}$. From the result obtained, the potassium chromate inhibitor has better inhibitory property than other inhibitors, which revealed that it is best suited for inhibition of corrosion of mild steel in seawater environment.
\end{abstract}

Keywords: Inhibition Efficiency, Inhibitor Concentration, Corrosion Rate, AISI 1019 Steel, Seawater Environment

\section{Introduction}

Corrosion is often referred to as metallic deterioration by chemical attack or reaction of a metal with its environment. [9]. Metallic corrosion is the passage of the metal into the chemically combined state. In other words, corrosion reactions cause metals to return to their natural ores. Aqueous Corrosion of any metal occurs by chemical reaction and by electrochemical mechanism. Corrosion may also be considered as a redox process in which an oxide coating is formed on the surface of the metal/alloy undergoing the process. It therefore requires oxygen and moisture to occur.

Corrosion is the transformation of metallic structures into other chemical structures, most often through the medium of a third structure, i.e., water. Often little or no corrosion would occur in the absence of water. It therefore requires oxygen and moisture to occur. Corrosion is in fact the "decay" of metals or alloy exposed to an aqueous environment. Corrosion of metals remains a universal scientific problem as it affects the metallurgical, chemical, food processing and oil Industries.

Corrosion inhibition is corrosion control by the addition of small quantities of chemical to an environment. Inhibitor function by lowering steady corrosion by reduction of metal loss in time and with time and also by extending the induction time for corrosion to commence [8].

Corrosion is a process not a property and it depends on a complex interaction between the material, its environment and the circumstances of exposure.

Considering the adverse effects of the damage caused by corrosion in various engineering field, there is the need to at least to retard the corrosion rate, if not to prevent it completely. The need for, and extent of corrosion control depends on the consequences of a failure [8]. An 
investigation into the subject of metallic corrosion is of immense industrial and academic concern and has thus received tangible interests throughout the years. The effect of immersion time and inhibitor concentration of Dill Seeds aqueous extract (DSAE) on the corrosion of C-steel in Red Sea Water was studied using chemical and electrochemical techniques [2]. It was found that the corrosion rate increases linearly with increasing immersion period although at a reduced rate due to the presence of Dill seeds aqueous extract (DSAE). The general corrosion processes of mild steel caused by the introduction of chloride ions and sulfate ions in simulated marine environment were studied by the measurements of open circuit potential (OCP), linear polarization resistance (LPR) and electrochemical impedance spectroscopy (EIS) methods [6].

OCP, LPR and EIS measurement results indicated that in simulated marine environment chloride ions had considerable influence on the passive film penetrate the corrosion product layer. Due to the corrosiveness of the marine environment and the susceptibility of carbon steel to corrosion, there is therefore the need to investigate the effect of inhibitor concentration and immersion time on the corrosion rate and inhibition efficiency of $0.19 \% \quad \mathrm{C}$ steel in seawater environment.

\section{Materials and Methods}

\subsection{Materials}

The material used in this research work is a mild steel substrate of $16 \mathrm{~mm}$ diameter. The chemical analysis of this material were carried out at the Environmental Laboratory of the Energy Research Centre, University of Benin using a mass spectrometer analyzer. The result of the analysis is shown in Table 1.

\subsubsection{Seawater}

The seawater used was collected from NPA Warri. The purpose of seawater analysis is to define the concentrations of the ions that are present in the water. In this research, the instrument used in measuring the seawater parameter is the YSI 556 multi-parameter system. This instrument is ready-touse, handheld system placed in the sampling area for measurements of dissolved oxygen, salinity, conductivity, $\mathrm{pH}$ and temperature. The composition of the seawater is shown in Table 2.

\subsubsection{Inhibitor}

The inhibitors used include Inorganic inhibitor: Potassium Chromate (PC) and Sodium Nitrite (SN), Organic Inhibitor: Methyl Orange (MO) and Methyl Red (MR) and Green Inhibitor: Terminalia Catappa Leaves (TCL) Extract and Carica Papaya Leaves (CPL) extract.

\subsection{Methods}

\subsubsection{Preparation of Mild Steel Sample}

The $16 \mathrm{~mm}$ diameter mild steel rod was machined into $85 \mathrm{~mm}$ length of forty-three (43) samples each. These were utilized for this experiment. The cut edges of each of the test samples were smoothened by silica carbide abrasive paper (emery paper from grade \#1000 to \#1200). They were degreased in a solution of $\mathrm{HCl}$ with acid to water ratio of 1 to 4 for 30 minutes at room temperature. They were then dried in open air and with clean cloth and stored in moisture free desiccators with silica gel blue before the commencement of corrosion studies and experimentation.

\subsubsection{Preparation of Green Inhibitor Solutions}

In order to prepare the extracts, leaves from Terminalia Catappa (TCL) and Carica Papaya (CPL) were obtained in their fresh forms from the tree, washed and subjected to drying under aerated or ventilated cover. This was done to ensure that the natural constituents of the leaves were not debased. A Soxhlet extractor was used to extract the leaves. The extract from the plant in the thimble dissolves into the warm reflux of methanol solvent and then the stable or nonvolatile extracts dissolved in the solvent were placed in a thermostated water bath heated at $55^{\circ} \mathrm{C}$ to drive off any methanol solvent that might be with the extracts. The extracts were stored in Petri dishes and covered. Corrosion inhibition performance in plant extracts is due to the presence of surface active constituents which normally enhance the film formation over the metal surface, thus mitigating corrosion.

\subsubsection{Preparation of Individual Organic and Inorganic Inhibitor Solutions}

The preparation of the individual inhibitor was carried out by weighing $2 \mathrm{~g}, 4 \mathrm{~g}, 6 \mathrm{~g}, 8 \mathrm{~g}$ and $10 \mathrm{~g}$ of Inorganic InhibitorPotassium Chromate (PC), Sodium Nitrite (SN), Organic Inhibitor-Methyl Orange (MO), Methyl Red (MR), Green Inhibitor-Terminalia Catappa leaves (TCL) and Carica Papaya leaves (CPL) using a sensitive digital analytical balance with accuracy to 0.0001 significant figures. These were dissolved in $500 \mathrm{~cm}^{3}$ beaker containing Seawater and stirred for complete dissolution. They were transferred into a $1000 \mathrm{~cm}^{3}$ (1 liter) volumetric flask and more water added up to the $1000 \mathrm{~cm}^{3}$ mark to obtain concentrations of $2 \mathrm{~g} / \mathrm{L}, 4 \mathrm{~g} / \mathrm{L}$, $6 \mathrm{~g} / \mathrm{L}, 8 \mathrm{~g} / \mathrm{L}$ and $10 \mathrm{~g} / \mathrm{L}$ of the inhibitor solution of PC, SN, MO and MR respectively. The percentages of the inhibitors in the prepared corrosive media are as follows: $2 \%, 4 \%, 6 \%, 8 \%$, and $10 \%$ respectively.

\subsubsection{Determination of Corrosion Rate from Weight Loss Measurement}

The investigation involves periodic weight loss measurement. Pre-cleaned and pre-weighed samples were fully and separately immersed in forty-three plastic containers containing natural seawater solution and varying concentrations of the inorganic, organic, green inhibitors, and the synergistic admixtures for sixty days (1440 hours). The corrosion samples were removed from the corrosion environments (media) with the aid of a tong after which the samples were properly cleaned in distilled water and then dried with a cotton wool.

The dried samples were weighed with a digital weighing balance and the average weight recorded at regular intervals 
of six (6) days for the duration of 60 days. From the data obtained, the weight loss, the corrosion rates were calculated [5].

(i) Corrosion Rate

$$
\text { Corrosion Rate, C. R (mmpy) }=\frac{87600 X \Delta W}{A X T X D}
$$

Where $\Delta \mathrm{W}=$ Weight loss (grams)

$\mathrm{A}=$ Surface Area for $16 \mathrm{~mm}$ diameter Mild Steel rod and $85 \mathrm{~mm}$ length

$$
\mathrm{A}==2 \mathrm{x} \pi \mathrm{xr}(\mathrm{r}+\mathrm{h})=2 \times 3.142 \times 1.6
$$

$(1.6+8.5)=10.0544 \times 10.1=101.54944 \mathrm{~cm}^{2}$
$\mathrm{D}=$ Density of Mild steel $=7.85 \mathrm{~g} / \mathrm{cm}^{3}$

$\mathrm{T}=$ Immersion time (hours)

The corrosion rate computed is presented in Table 3 .

(ii) Inhibition Efficiency

Inhibition Efficiency $=\frac{C \cdot R_{C O N T R O L-C \cdot R_{I N H I B I T E D}}}{C \cdot R_{C O N T R O L}} \times 100(2)$

Where C. R CONTROL=The corrosion rate without inhibitor

C. $\mathrm{R}$ INHIBITED=The corrosion rate in the presence of an inhibitor

The inhibition efficiency is presented in Table 4.

\section{Results and Discussion}

\subsection{Results}

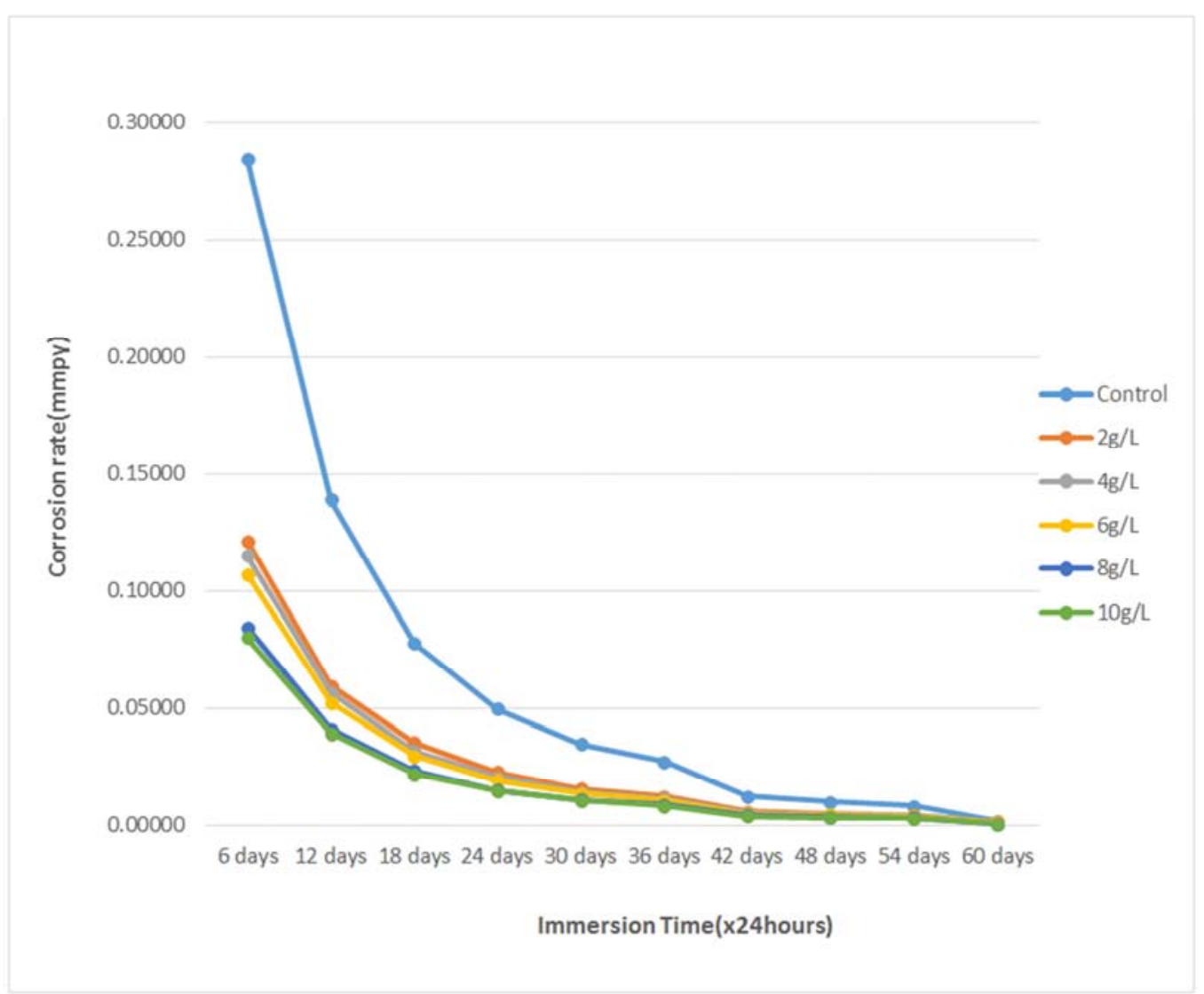

Figure 1. Plot of Corrosion Rate (mmpy) against Immersion Time (hours) for Mild Steel in Seawater in the Presence of Varied Potassium Chromate Inhibitor.

\begin{tabular}{|c|c|c|c|c|c|c|c|c|c|c|c|c|c|}
\hline Element & $\mathrm{Fe}$ & $\mathrm{C}$ & $\mathbf{S i}$ & Mn & $\mathbf{P}$ & $\mathbf{S}$ & $\mathrm{Cu}$ & $\mathbf{N i}$ & $\mathrm{Cr}$ & Mo & Al & W & $\mathbf{N}$ \\
\hline Composition & 98.23 & 0.19 & 0.27 & 0.83 & 0.024 & 0.028 & 0.25 & 0.07 & 0.06 & 0.007 & 0.026 & 0.008 & 0.007 \\
\hline
\end{tabular}

Table 1. Chemical composition of the mild steel.

Table 2. Physio-chemical condition of the seawater.

\begin{tabular}{ll}
\hline Parameter & Value \\
\hline Electrical Conductivity $(\mathrm{scm}-1)$ & 1790 \\
Temperature $\left({ }^{\circ} \mathrm{C}\right)$ & 27.6 \\
Total Dissolved Salts $(\mathrm{TDS})(\mathrm{mg} / \mathrm{L})$ & 835 \\
Dissolved Oxygen $(\mathrm{DO})(\mathrm{mg} / \mathrm{L})$ & 6.9 \\
$\mathrm{pH}$ & 6.65 \\
Free ammonia as NH3 $(\mathrm{mg} / \mathrm{L})$ & 1.21 \\
\hline
\end{tabular}




\begin{tabular}{ll}
\hline Parameter & Value \\
\hline Chloride as Cl- $(\mathrm{mg} / \mathrm{L})$ & 0.15 \\
Chemical Oxygen Demand (COD) & 3.13 \\
Sulphate as SO4 $(\mathrm{mg} / \mathrm{L})$ & 75 \\
Nitrate as NO3 $(\mathrm{Mg} / \mathrm{L})$ & 16.5 \\
Phosphate as PO4 $(\mathrm{Mg} / \mathrm{L})$ & 16.82 \\
\hline
\end{tabular}

Table 3. Corrosion Rate (mmpy) of AISI 1019 Steel in Seawater at Varying Inhibitor Concentration and Immersion time.

\begin{tabular}{|c|c|c|c|c|c|c|c|c|c|c|c|}
\hline Inhibitor & Concentration & $\begin{array}{l}\text { Corrosion } \\
\text { Rate at } \\
\text { day6 }\end{array}$ & $\begin{array}{l}\text { Corrosion } \\
\text { Rate at } \\
\text { day12 }\end{array}$ & $\begin{array}{l}\text { Corrosion } \\
\text { Rate at } \\
\text { day18 }\end{array}$ & $\begin{array}{l}\text { Corrosion } \\
\text { Rate at } \\
\text { day } 24\end{array}$ & $\begin{array}{l}\text { Corrosion } \\
\text { Rate at } \\
\text { day30 }\end{array}$ & $\begin{array}{l}\text { Corrosion } \\
\text { Rate at } \\
\text { day36 }\end{array}$ & $\begin{array}{l}\text { Corrosion } \\
\text { Rate at } \\
\text { day42 }\end{array}$ & $\begin{array}{l}\text { Corrosion } \\
\text { Rate at } \\
\text { day48 }\end{array}$ & $\begin{array}{l}\text { Corrosion } \\
\text { Rate at } \\
\text { day54 }\end{array}$ & $\begin{array}{l}\text { Corrosion } \\
\text { Rate at } \\
\text { day60 }\end{array}$ \\
\hline \multirow{5}{*}{$\begin{array}{l}\text { Potassium } \\
\text { Chromate } \\
\text { (PC) }\end{array}$} & $2 \mathrm{~g} / \mathrm{L}$ & 0.1214 & 0.0594 & 0.0354 & 0.0228 & 0.0157 & 0.0127 & 0.0059 & 0.0050 & 0.0044 & 0.0016 \\
\hline & $4 \mathrm{~g} / \mathrm{L}$ & 0.1150 & 0.0569 & 0.0318 & 0.0207 & 0.0142 & 0.0116 & 0.0055 & 0.0045 & 0.0040 & 0.0013 \\
\hline & $6 \mathrm{~g} / \mathrm{L}$ & 0.1071 & 0.0528 & 0.0296 & 0.0192 & 0.0135 & 0.0108 & 0.0052 & 0.0043 & 0.0036 & 0.0011 \\
\hline & $8 \mathrm{~g} / \mathrm{L}$ & 0.0846 & 0.0414 & 0.0232 & 0.0150 & 0.0111 & 0.0089 & 0.0041 & 0.0035 & 0.0031 & 0.0008 \\
\hline & $10 \mathrm{~g} / \mathrm{L}$ & 0.0799 & 0.0392 & 0.0222 & 0.0148 & 0.0108 & 0.0085 & 0.0040 & 0.0033 & 0.0029 & 0.0007 \\
\hline \multirow{4}{*}{$\begin{array}{l}\text { Sodium } \\
\text { Nitrite } \\
(\mathrm{SN})\end{array}$} & $4 \mathrm{~g} / \mathrm{L}$ & 0.1292 & 0.0636 & 0.0359 & 0.0231 & 0.0163 & 0.0131 & 0.0060 & 0.0050 & 0.0043 & 0.0013 \\
\hline & $6 \mathrm{~g} / \mathrm{L}$ & 0.1144 & 0.0562 & 0.0315 & 0.0203 & 0.0144 & 0.0113 & 0.0053 & 0.0044 & 0.0037 & 0.0009 \\
\hline & $8 \mathrm{~g} / \mathrm{L}$ & 0.1090 & 0.0536 & 0.0301 & 0.0193 & 0.0137 & 0.0108 & 0.0051 & 0.0042 & 0.0036 & 0.0009 \\
\hline & $10 \mathrm{~g} / \mathrm{L}$ & 0.1016 & 0.0499 & 0.0281 & 0.0180 & 0.0129 & 0.0101 & 0.0048 & 0.0040 & 0.0034 & 0.0009 \\
\hline \multirow{3}{*}{$\begin{array}{l}\text { Methyl } \\
\text { Orange } \\
\text { (MO) }\end{array}$} & $2 \mathrm{~g} / \mathrm{L}$ & 0.1274 & 0.0625 & 0.0350 & 0.0225 & 0.0165 & 0.0133 & 0.0061 & 0.0051 & 0.0044 & 0.0013 \\
\hline & $4 \mathrm{~g} / \mathrm{L}$ & 0.1178 & 0.0580 & 0.0327 & 0.0214 & 0.0153 & 0.0122 & 0.0058 & 0.0048 & 0.0041 & 0.0013 \\
\hline & $6 \mathrm{~g} / \mathrm{L}$ & 0.1112 & 0.0549 & 0.0325 & 0.0213 & 0.0152 & 0.0116 & 0.0054 & 0.0044 & 0.0038 & 0.0009 \\
\hline \multirow{5}{*}{$\begin{array}{l}\text { Methyl } \\
\text { Red (MR) }\end{array}$} & $2 \mathrm{~g} / \mathrm{L}$ & 0.1149 & 0.0562 & 0.0324 & 0.0213 & 0.0154 & 0.0121 & 0.0058 & 0.0048 & 0.0041 & 0.0012 \\
\hline & $4 \mathrm{~g} / \mathrm{L}$ & 0.1000 & 0.0488 & 0.0277 & 0.0183 & 0.0132 & 0.0109 & 0.0051 & 0.0042 & 0.0039 & 0.0010 \\
\hline & $6 \mathrm{~g} / \mathrm{L}$ & 0.0942 & 0.0462 & 0.0259 & 0.0184 & 0.0130 & 0.0104 & 0.0050 & 0.0042 & 0.0035 & 0.0010 \\
\hline & $8 \mathrm{~g} / \mathrm{L}$ & 0.0938 & 0.0458 & 0.0258 & 0.0168 & 0.0125 & 0.0100 & 0.0049 & 0.0040 & 0.0034 & 0.0005 \\
\hline & $10 \mathrm{~g} / \mathrm{L}$ & 0.0902 & 0.0442 & 0.0253 & 0.0166 & 0.0120 & 0.0096 & 0.0047 & 0.0039 & 0.0033 & 0.0008 \\
\hline Terminalia & $2 \mathrm{~g} / \mathrm{L}$ & 0.1406 & 0.0690 & 0.0386 & 0.0250 & 0.0179 & 0.0141 & 0.0065 & 0.0054 & 0.0046 & 0.0012 \\
\hline Catappa & $4 \mathrm{~g} / \mathrm{L}$ & 0.1190 & 0.0586 & 0.0341 & 0.0222 & 0.0158 & 0.0127 & 0.0062 & 0.0051 & 0.0043 & 0.0010 \\
\hline Leaves & $6 \mathrm{~g} / \mathrm{L}$ & 0.1071 & 0.0524 & 0.0305 & 0.0219 & 0.0153 & 0.0122 & 0.0056 & 0.0047 & 0.0040 & 0.0010 \\
\hline (TCL) & $8 \mathrm{~g} / \mathrm{L}$ & 0.1041 & 0.0508 & 0.0298 & 0.0199 & 0.0144 & 0.0117 & 0.0054 & 0.0044 & 0.0037 & 0.0009 \\
\hline Extract & $10 \mathrm{~g} / \mathrm{L}$ & 0.1018 & 0.0498 & 0.0296 & 0.0198 & 0.0144 & 0.0116 & 0.0053 & 0.0044 & 0.0037 & 0.0009 \\
\hline Carica & $2 \mathrm{~g} / \mathrm{L}$ & 0.1497 & 0.0737 & 0.0413 & 0.0265 & 0.0190 & 0.0150 & 0.0072 & 0.0059 & 0.0050 & 0.0012 \\
\hline Papaya & $4 \mathrm{~g} / \mathrm{L}$ & 0.1357 & 0.0665 & 0.0380 & 0.0252 & 0.0183 & 0.0148 & 0.0067 & 0.0056 & 0.0047 & 0.0011 \\
\hline Leaves & $6 \mathrm{~g} / \mathrm{L}$ & 0.1274 & 0.0625 & 0.0351 & 0.0229 & 0.0166 & 0.0133 & 0.0063 & 0.0052 & 0.0044 & 0.0010 \\
\hline (CPL) & $8 \mathrm{~g} / \mathrm{L}$ & 0.1212 & 0.0597 & 0.0339 & 0.0218 & 0.0156 & 0.0123 & 0.0058 & 0.0048 & 0.0042 & 0.0010 \\
\hline Extract & $10 \mathrm{~g} / \mathrm{L}$ & 0.1145 & 0.0563 & 0.0321 & 0.0207 & 0.0149 & 0.0118 & 0.0057 & 0.0047 & 0.0040 & 0.0009 \\
\hline
\end{tabular}

Table 4. Inhibition Efficiency (\%) of Mild Steel in Seawater at Varying Inhibitor Concentration and Immersion Time.

\begin{tabular}{|c|c|c|c|c|c|c|c|c|c|c|c|}
\hline Inhibitor & Concentration & $\begin{array}{l}\text { Inhibitor } \\
\text { Efficiency } \\
\text { at day6 }\end{array}$ & $\begin{array}{l}\text { Inhibitor } \\
\text { Efficiency } \\
\text { at day12 }\end{array}$ & $\begin{array}{l}\text { Inhibitor } \\
\text { Efficiency } \\
\text { at day18 }\end{array}$ & $\begin{array}{l}\text { Inhibitor } \\
\text { Efficiency } \\
\text { at day24 }\end{array}$ & $\begin{array}{l}\text { Inhibitor } \\
\text { Efficiency } \\
\text { at day30 }\end{array}$ & $\begin{array}{l}\text { Inhibitor } \\
\text { Efficiency } \\
\text { at day36 }\end{array}$ & $\begin{array}{l}\text { Inhibitor } \\
\text { Efficiency } \\
\text { at day } 42\end{array}$ & $\begin{array}{l}\text { Inhibitor } \\
\text { Efficiency } \\
\text { at day48 }\end{array}$ & $\begin{array}{l}\text { Inhibitor } \\
\text { Efficiency } \\
\text { at day54 }\end{array}$ & $\begin{array}{l}\text { Inhibitor } \\
\text { Efficiency } \\
\text { at day60 }\end{array}$ \\
\hline \multirow{5}{*}{$\begin{array}{l}\text { Potassium } \\
\text { Chromate } \\
\text { (PC) }\end{array}$} & $2 \mathrm{~g} / \mathrm{L}$ & $57.39 \%$ & $57.25 \%$ & $54.40 \%$ & $54.17 \%$ & $54.76 \%$ & $53.34 \%$ & $52.27 \%$ & $50.35 \%$ & $47.92 \%$ & $19.05 \%$ \\
\hline & $4 \mathrm{~g} / \mathrm{L}$ & $59.62 \%$ & $59.05 \%$ & $59.08 \%$ & $58.36 \%$ & $59.13 \%$ & $57.43 \%$ & $55.76 \%$ & $55.15 \%$ & $53.19 \%$ & $32.60 \%$ \\
\hline & $6 \mathrm{~g} / \mathrm{L}$ & $62.39 \%$ & $62.03 \%$ & $61.87 \%$ & $61.44 \%$ & $61.14 \%$ & $60.48 \%$ & $58.44 \%$ & $57.59 \%$ & $57.53 \%$ & $45.42 \%$ \\
\hline & $8 \mathrm{~g} / \mathrm{L}$ & $70.29 \%$ & $70.25 \%$ & $70.08 \%$ & $69.83 \%$ & $68.16 \%$ & $67.28 \%$ & $67.05 \%$ & $65.18 \%$ & $63.71 \%$ & $59.34 \%$ \\
\hline & $10 \mathrm{~g} / \mathrm{L}$ & $71.94 \%$ & $71.77 \%$ & $71.43 \%$ & $70.29 \%$ & $69.06 \%$ & $68.88 \%$ & $68.02 \%$ & $67.10 \%$ & $65.37 \%$ & $62.64 \%$ \\
\hline \multirow{4}{*}{$\begin{array}{l}\text { Sodium } \\
\text { Nitrite (SN) }\end{array}$} & $4 \mathrm{~g} / \mathrm{L}$ & $54.64 \%$ & $54.22 \%$ & $53.74 \%$ & $53.53 \%$ & $53.07 \%$ & $52.04 \%$ & $51.30 \%$ & $50.52 \%$ & $49.77 \%$ & $33.70 \%$ \\
\hline & $6 \mathrm{~g} / \mathrm{L}$ & $59.82 \%$ & $59.59 \%$ & $59.49 \%$ & $59.27 \%$ & $58.72 \%$ & $58.54 \%$ & $57.63 \%$ & $56.37 \%$ & $56.23 \%$ & $53.48 \%$ \\
\hline & $8 \mathrm{~g} / \mathrm{L}$ & $61.71 \%$ & $61.42 \%$ & $61.30 \%$ & $61.22 \%$ & $60.48 \%$ & $60.31 \%$ & $59.25 \%$ & $58.20 \%$ & $57.34 \%$ & $54.95 \%$ \\
\hline & $10 \mathrm{~g} / \mathrm{L}$ & $64.34 \%$ & $64.07 \%$ & $63.85 \%$ & $63.83 \%$ & $63.06 \%$ & $62.81 \%$ & $61.53 \%$ & $60.73 \%$ & $59.46 \%$ & $55.68 \%$ \\
\hline \multirow{4}{*}{$\begin{array}{l}\text { Methyl } \\
\text { Orange } \\
\text { (MO) }\end{array}$} & $2 \mathrm{~g} / \mathrm{L}$ & $55.28 \%$ & $55.04 \%$ & $54.96 \%$ & $54.81 \%$ & $52.47 \%$ & $51.27 \%$ & $50.73 \%$ & $49.13 \%$ & $48.29 \%$ & $31.50 \%$ \\
\hline & $4 \mathrm{~g} / \mathrm{L}$ & $58.62 \%$ & $58.27 \%$ & $57.95 \%$ & $57.01 \%$ & $56.12 \%$ & $55.40 \%$ & $53.08 \%$ & $52.53 \%$ & $51.34 \%$ & $34.80 \%$ \\
\hline & $6 \mathrm{~g} / \mathrm{L}$ & $60.95 \%$ & $60.47 \%$ & $58.20 \%$ & $57.21 \%$ & $56.44 \%$ & $57.43 \%$ & $56.57 \%$ & $56.37 \%$ & $55.12 \%$ & $54.21 \%$ \\
\hline & $10 \mathrm{~g} / \mathrm{L}$ & $68.94 \%$ & $68.36 \%$ & $68.08 \%$ & $67.91 \%$ & $66.77 \%$ & $66.51 \%$ & $65.50 \%$ & $64.83 \%$ & $64.13 \%$ & $63.37 \%$ \\
\hline \multirow{5}{*}{$\begin{array}{l}\text { Methyl Red } \\
\text { (MR) }\end{array}$} & $2 \mathrm{~g} / \mathrm{L}$ & $59.66 \%$ & $59.56 \%$ & $58.25 \%$ & $57.15 \%$ & $55.75 \%$ & $55.57 \%$ & $53.08 \%$ & $52.09 \%$ & $51.43 \%$ & $35.53 \%$ \\
\hline & $4 \mathrm{~g} / \mathrm{L}$ & $64.88 \%$ & $64.88 \%$ & $64.36 \%$ & $63.16 \%$ & $62.11 \%$ & $59.92 \%$ & $59.01 \%$ & $58.03 \%$ & $54.02 \%$ & $46.52 \%$ \\
\hline & $6 \mathrm{~g} / \mathrm{L}$ & $66.91 \%$ & $66.76 \%$ & $66.62 \%$ & $63.06 \%$ & $62.52 \%$ & $62.03 \%$ & $60.06 \%$ & $58.29 \%$ & $58.17 \%$ & $49.45 \%$ \\
\hline & $8 \mathrm{~g} / \mathrm{L}$ & $67.06 \%$ & $67.04 \%$ & $66.81 \%$ & $66.35 \%$ & $64.10 \%$ & $63.50 \%$ & $60.47 \%$ & $60.38 \%$ & $59.83 \%$ & $74.36 \%$ \\
\hline & $10 \mathrm{~g} / \mathrm{L}$ & $68.32 \%$ & $68.18 \%$ & $67.50 \%$ & $66.60 \%$ & $65.60 \%$ & $64.83 \%$ & $62.18 \%$ & $61.61 \%$ & $61.31 \%$ & $59.71 \%$ \\
\hline
\end{tabular}




\begin{tabular}{|c|c|c|c|c|c|c|c|c|c|c|c|}
\hline Inhibitor & Concentration & $\begin{array}{l}\text { Inhibitor } \\
\text { Efficiency } \\
\text { at day6 }\end{array}$ & $\begin{array}{l}\text { Inhibitor } \\
\text { Efficiency } \\
\text { at day12 }\end{array}$ & $\begin{array}{l}\text { Inhibitor } \\
\text { Efficiency } \\
\text { at day18 }\end{array}$ & $\begin{array}{l}\text { Inhibitor } \\
\text { Efficiency } \\
\text { at day24 }\end{array}$ & $\begin{array}{l}\text { Inhibitor } \\
\text { Efficiency } \\
\text { at day30 }\end{array}$ & $\begin{array}{l}\text { Inhibitor } \\
\text { Efficiency } \\
\text { at day36 }\end{array}$ & $\begin{array}{l}\text { Inhibitor } \\
\text { Efficiency } \\
\text { at day } 42\end{array}$ & $\begin{array}{l}\text { Inhibitor } \\
\text { Efficiency } \\
\text { at day48 }\end{array}$ & $\begin{array}{l}\text { Inhibitor } \\
\text { Efficiency } \\
\text { at day54 }\end{array}$ & $\begin{array}{l}\text { Inhibitor } \\
\text { Efficiency } \\
\text { at day60 }\end{array}$ \\
\hline Terminalia & $2 g / L$ & $50.63 \%$ & $50.33 \%$ & $50.33 \%$ & $49.72 \%$ & $48.46 \%$ & $48.17 \%$ & $47.89 \%$ & $46.16 \%$ & $45.43 \%$ & $37.36 \%$ \\
\hline Catappa & $4 \mathrm{~g} / \mathrm{L}$ & $58.23 \%$ & $57.84 \%$ & $56.10 \%$ & $55.45 \%$ & $54.45 \%$ & $53.29 \%$ & $49.76 \%$ & $49.48 \%$ & $49.31 \%$ & $49.08 \%$ \\
\hline Leaves & $6 \mathrm{~g} / \mathrm{L}$ & $62.41 \%$ & $62.27 \%$ & $60.73 \%$ & $56.09 \%$ & $55.87 \%$ & $55.14 \%$ & $55.03 \%$ & $53.58 \%$ & $53.28 \%$ & $50.18 \%$ \\
\hline (TCL) & $8 \mathrm{~g} / \mathrm{L}$ & $63.45 \%$ & $63.41 \%$ & $61.64 \%$ & $60.09 \%$ & $58.55 \%$ & $57.04 \%$ & $56.17 \%$ & $56.02 \%$ & $55.96 \%$ & $53.48 \%$ \\
\hline Extract & $10 \mathrm{~g} / \mathrm{L}$ & $64.27 \%$ & $64.15 \%$ & $61.91 \%$ & $60.30 \%$ & $58.59 \%$ & $57.51 \%$ & $57.47 \%$ & $56.81 \%$ & $56.69 \%$ & $54.95 \%$ \\
\hline Carica & $2 \mathrm{~g} / \mathrm{L}$ & $47.44 \%$ & $46.96 \%$ & $46.82 \%$ & $46.78 \%$ & $45.50 \%$ & $45.16 \%$ & $41.80 \%$ & $41.27 \%$ & $40.90 \%$ & $36.63 \%$ \\
\hline Papaya & $4 \mathrm{~g} / \mathrm{L}$ & $52.36 \%$ & $52.16 \%$ & $51.09 \%$ & $49.47 \%$ & $47.49 \%$ & $45.93 \%$ & $45.62 \%$ & $45.03 \%$ & $44.78 \%$ & $43.22 \%$ \\
\hline Leaves & $6 \mathrm{~g} / \mathrm{L}$ & $55.28 \%$ & $55.02 \%$ & $54.80 \%$ & $54.04 \%$ & $52.23 \%$ & $51.10 \%$ & $49.27 \%$ & $48.52 \%$ & $48.29 \%$ & $47.99 \%$ \\
\hline (CPL) & $8 \mathrm{~g} / \mathrm{L}$ & $57.44 \%$ & $57.02 \%$ & $56.38 \%$ & $56.19 \%$ & $55.22 \%$ & $54.97 \%$ & $53.33 \%$ & $52.01 \%$ & $50.60 \%$ & $48.72 \%$ \\
\hline Extract & $10 \mathrm{~g} / \mathrm{L}$ & $59.79 \%$ & $59.48 \%$ & $58.73 \%$ & $58.35 \%$ & $57.05 \%$ & $56.78 \%$ & $54.14 \%$ & $53.93 \%$ & $53.00 \%$ & $51.28 \%$ \\
\hline
\end{tabular}

Figure 1 show the variation of the Corrosion Penetration Rate (mm/yr.) against the Immersion time (hours) recorded for various concentrations of Potassium Chromate (PC) at 6 days' interval for 60 days.

From the graph, the corrosion rate decreases with increase in inhibitor concentration and decreases as the experiment progresses. The corrosion rate of mild steel in the control solution is almost twice as fast as the corrosion rate of the mild steel in the inhibited potassium chromate solutions.

The inhibitor solution with a concentration of $10 \mathrm{~g} / \mathrm{L}$ exhibits the lowest rate of corrosion of the mild steel while the inhibitor solution with a concentration of $2 \mathrm{~g} / \mathrm{L}$ exhibits the highest rate of the mild steel.

Figure 2 show the variation of the Corrosion Penetration Rate (mm/yr.) against the Immersion time (hours) recorded for mild steel with various concentrations of Sodium Nitrite (SN) Inhibitor at 6 days' interval for 60 days.

As shown in the figure above, there is a marked decrease in the corrosion rate as the inhibitor concentration increases. The corrosion rate decreases as the immersion time increases. The trends reveal that the corrosion rate is lowest at the $10 \mathrm{~g} / \mathrm{L}$ inhibitor concentration and the corrosion rate is highest at the $2 \mathrm{~g} / \mathrm{L}$ inhibitor concentration.
Figure 3 show the variation of the Corrosion Penetration Rate (mm/yr.) against the Immersion Time (hours) recorded for mild steel with various concentrations of Methyl Orange (MO) Inhibitor at 6 days' interval for 60 days.

As obtained in the figure above there is a trivial difference recorded for the corrosion rates for $2 \mathrm{~g} / \mathrm{L}, 4 \mathrm{~g} / \mathrm{L}$, and $6 \mathrm{~g} / \mathrm{L}$ concentrations. A significant decrease in corrosion rate occurs at a concentration of $8 \mathrm{~g} / \mathrm{L}$ and $10 \mathrm{~g} / \mathrm{L}$. The corrosion rate also decreases with immersion time as more of the inhibitor is absorbed.

Figure 4 show the variation of the Corrosion Penetration Rate (mm/yr.) against the Immersion time (hours) recorded for mild Steel in seawater for various concentrations of Methyl Red (MR) Inhibitor at 6 days' interval for 60 days.

The corrosion rate decreases with increase in inhibitor concentration and decreases as the experiment progresses. The corrosion rates at the 6 th day for the $4 \mathrm{~g} / \mathrm{L}, 6 \mathrm{~g} / \mathrm{L}, 8 \mathrm{~g} / \mathrm{L}$, and $10 \mathrm{~g} / \mathrm{L}$ inhibitor concentration are all below $0.1 \mathrm{~mm}$ per year while that for the $2 \mathrm{~g} / \mathrm{L}$ concentration is about $0.12 \mathrm{~mm}$ per year suggesting a high rate of corrosion for low inhibitor concentration. There is a substantial difference between the corrosion rate for the control (seawater) and the inhibited solutions.

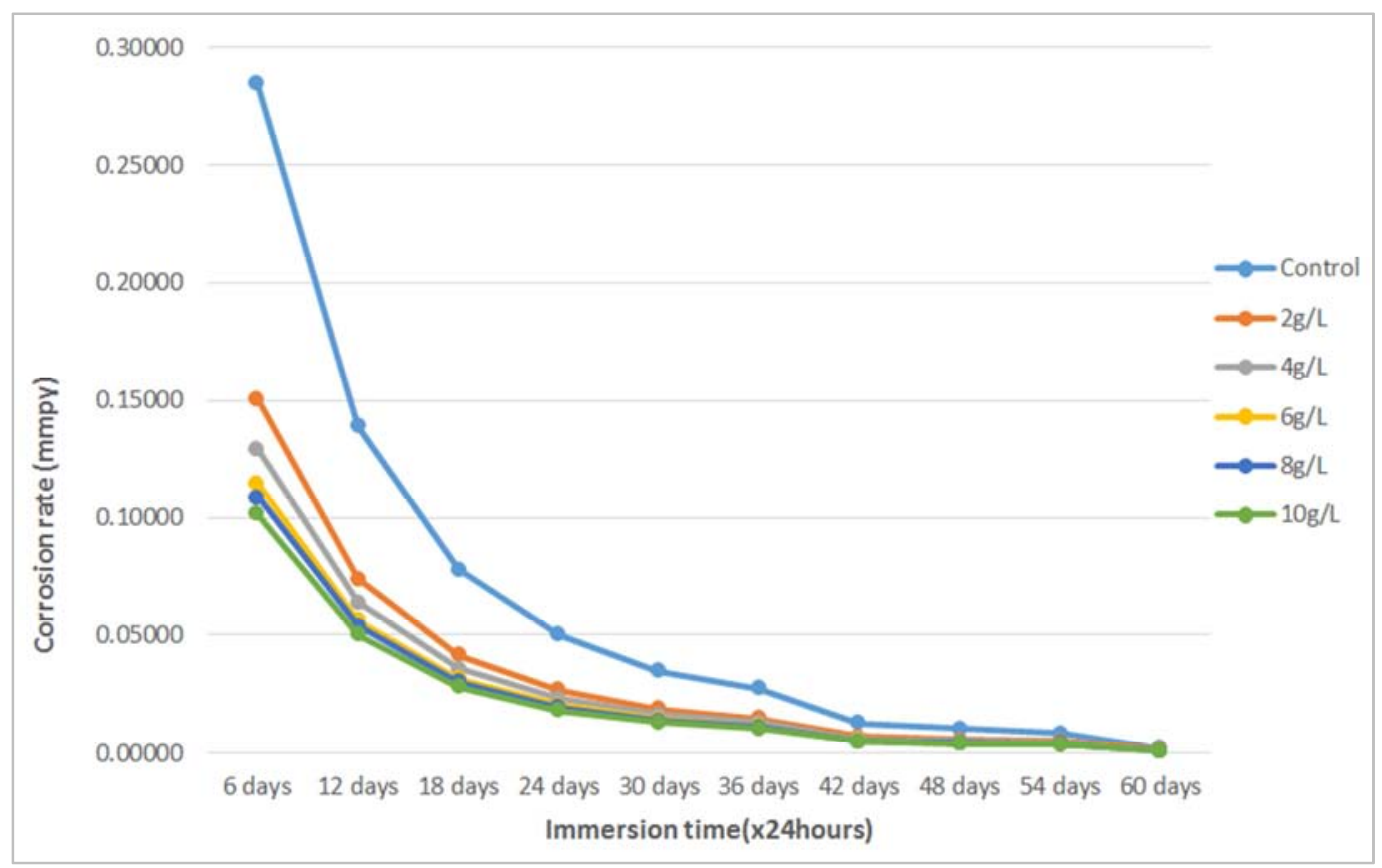

Figure 2. Plot of Corrosion Rate (mmpy) against Immersion Time (hours) for Mild Steel in Seawater in the Presence of Varied Sodium Nitrite Inhibitor. 


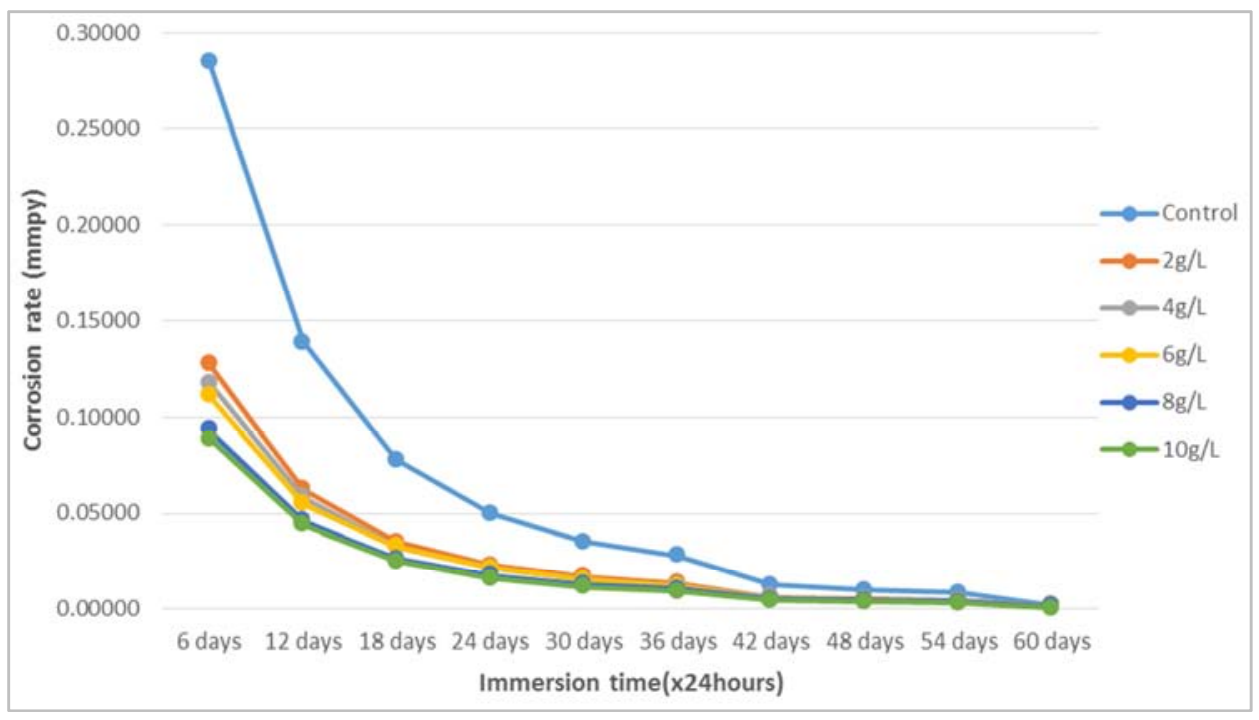

Figure 3. Plot of Corrosion Rate (mmpy) against Immersion Time (hours) for Mild Steel in Seawater in the Presence of Varied Methyl Orange Inhibitor.

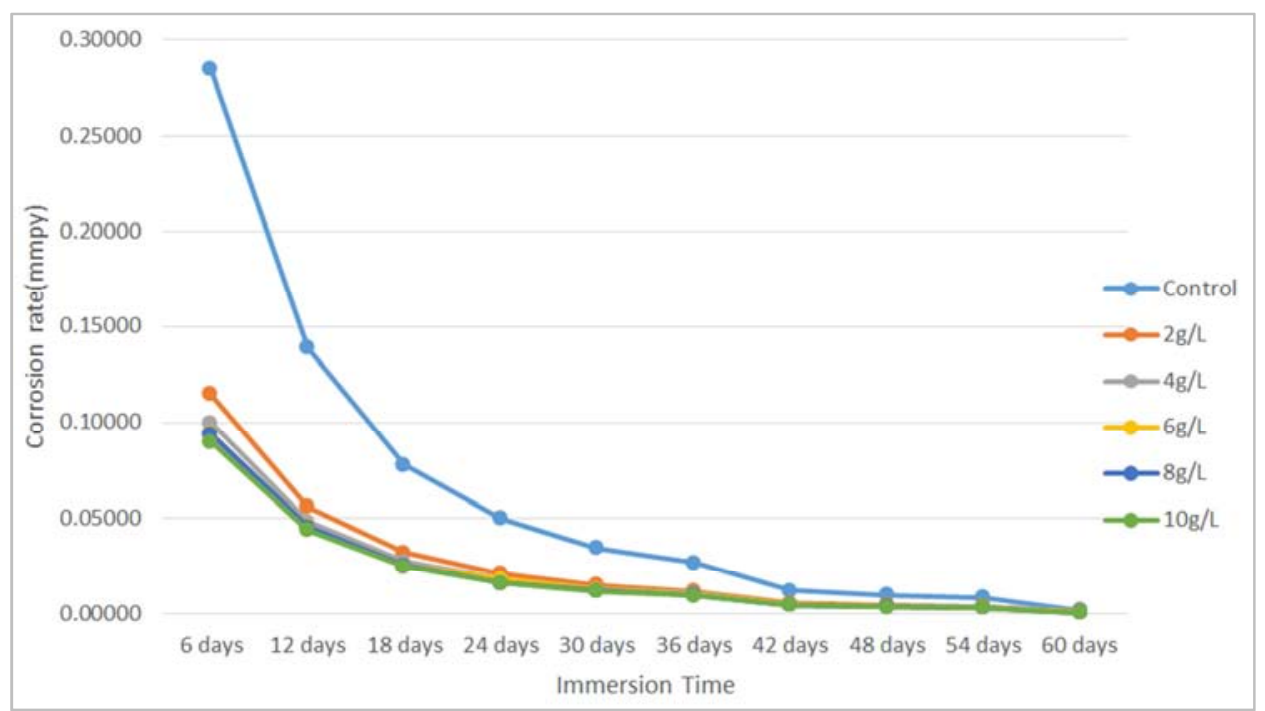

Figure 4. Plot of Corrosion Rate (mmpy) against Immersion Time (hours) for Mild Steel in Seawater in the Presence of Varied Methyl Red Inhibitor.

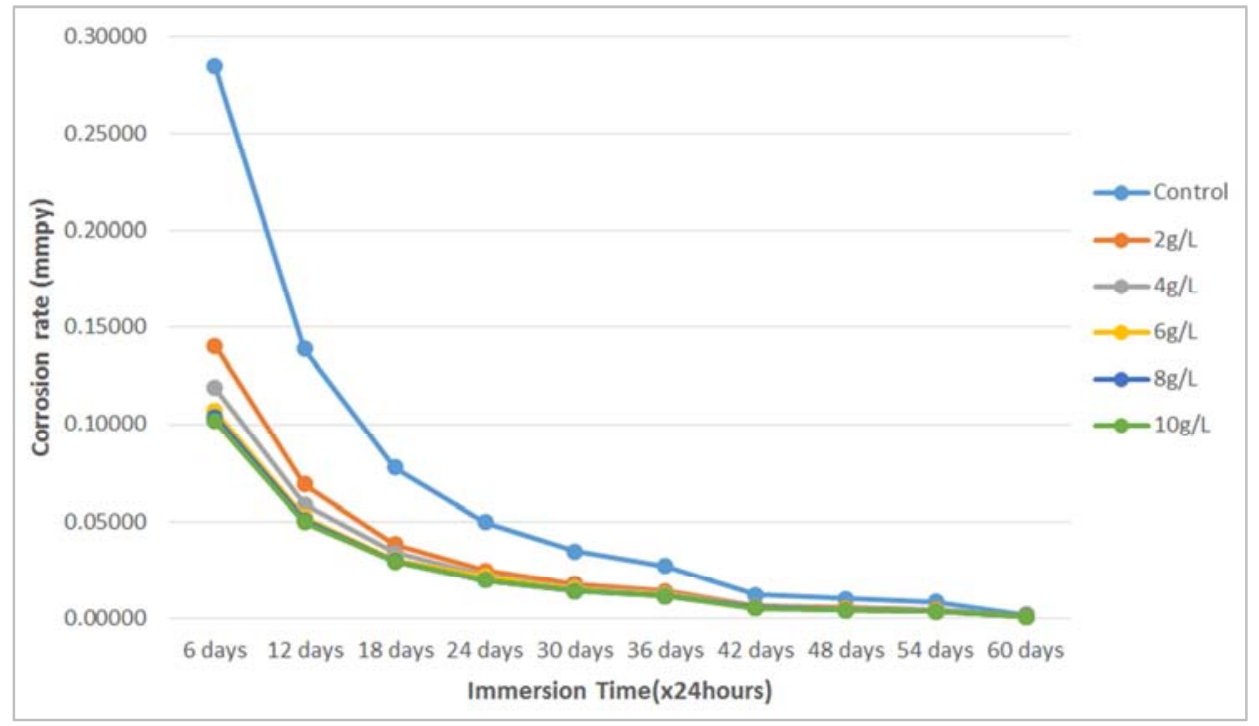

Figure 5. Plot of Corrosion Rate (mmpy) against Immersion Time (hours) for Mild Steel in Seawater in the Presence of Varied Terminalia Catappa Leaves Extract Inhibitor. 
Figure 5 show the variation of the Corrosion Penetration Rate (mm/yr.) against the Immersion time (hours) recorded for Mild Steel in Seawater for various concentrations of Terminalia Catappa Leaves (TCL) Extract commonly called “tropical almond" leaves extract Inhibitor at 6 days' interval for 60 days.

The corrosion rate is generally seen to decrease with inhibitor concentration and decrease as the experiment progresses
The rate of corrosion of the mild steel is slightly reduced with the introduction of this inhibitor as compared to the selected inhibitor as the difference between the corrosion rate for the control and the inhibited solutions is small. The corrosion rate obtained at sixth day is greater than $0.1 \mathrm{~mm}$ per year for all the concentration. At the 60th day, there is generally no effect of the corrosion inhibitor as the difference in corrosion rate for both control (seawater) and inhibitor solutions is negligible.

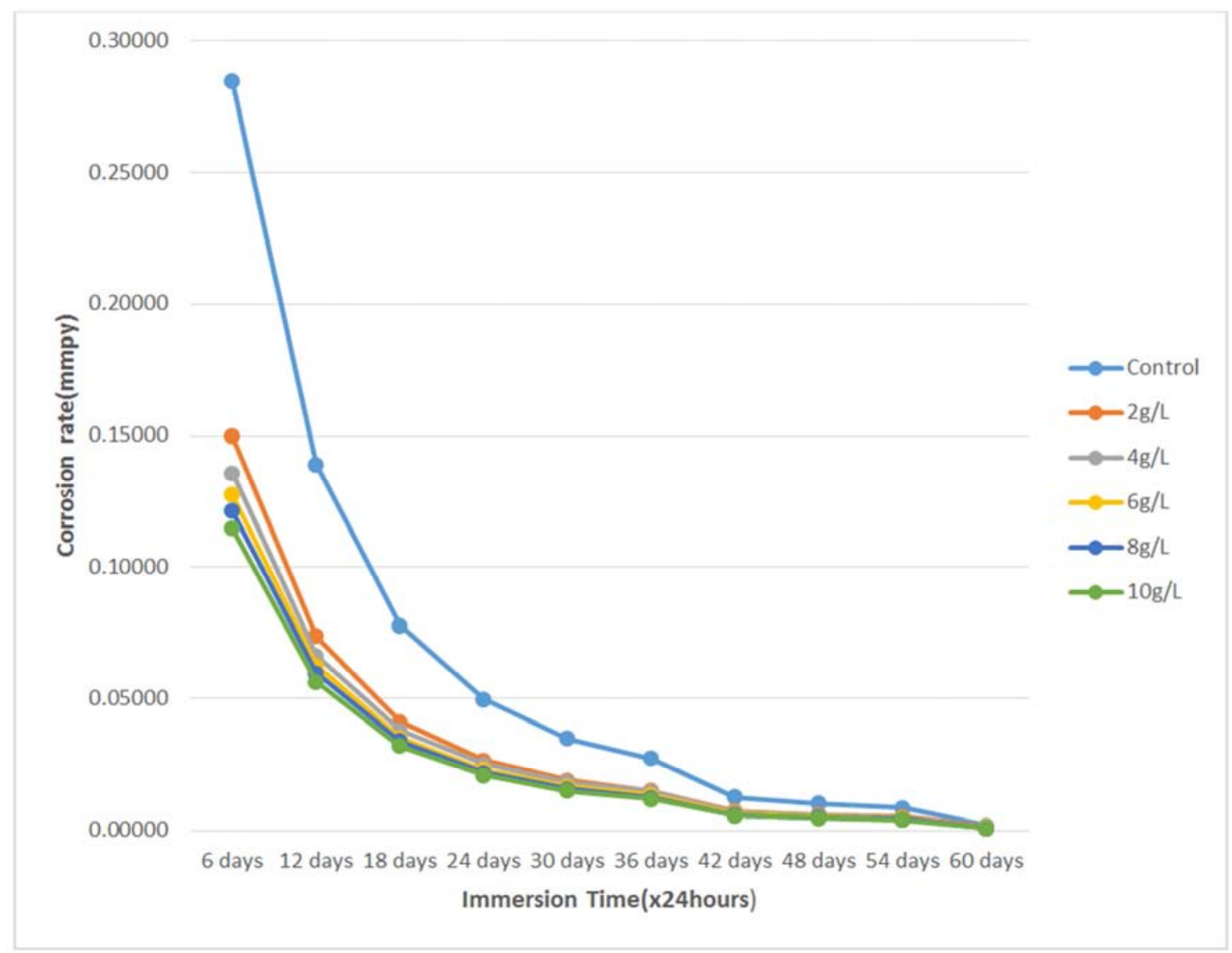

Figure 6. Plot of Corrosion Rate (mmpy) against Immersion Time (hours) for Mild Steel in Seawater in the Presence of Varied Carica Papaya Leaves (CPL) Extract Inhibitor.

Figure 6 show the variation of the Corrosion Penetration Rate (mm/yr.) against the Immersion time (hours) recorded for Mild Steel in Seawater for various concentrations of Carica Papaya Leaves (CPL) Extract commonly called "pawpaw tree" leaves extract Inhibitor at 6 days' interval for 60 days.

The graph demonstrates that at the 6th day, the rate of corrosion is higher than $0.10 \mathrm{~mm}$ per year for all inhibitor concentrations while there is almost no effect of the inhibitor from the 60th day. There is decrease in corrosion rate as the inhibitor concentration increases. The corrosion rate decreases as the experiment progresses as a result of the inhibitor that has been fully absorbed and the formation of active protective film.

Figure 7 show Inhibition efficiency of Potassium Chromate (PC) inhibitor on the corrosion of mild Steel in seawater at day 6 (144hours) with various Inhibitor concentrations.

The important finding from the figure above reveals that the inhibitor efficiency increased with increase in inhibitor concentration.

It is also visible that a substantial increase in the inhibitor efficiency is noticed at the inhibitor concentration of $8 \mathrm{~g} / \mathrm{L}$ and $10 \mathrm{~g} / \mathrm{L}$. There is a little difference in inhibitor efficiency between the $2 \mathrm{~g} / \mathrm{L}$ inhibitor concentration and the $4 \mathrm{~g} / \mathrm{L}$ inhibitor concentration.

Figure 8 show Inhibition efficiency of Potassium Chromate (PC) inhibitor on the corrosion of mild steel in seawater at day 60 (1440hours) with various Inhibitor concentrations.

There is a reduction in the inhibition efficiency at the 60th day. From the series, the inhibition efficiency is also seen to increase with inhibitor concentration. At the point of $8 \mathrm{~g} / \mathrm{L}$ 
and $10 \mathrm{~g} / \mathrm{L}$, the inhibitor efficiency has a notable increase suggesting that the corrosion inhibitors molecules were fully absorbed on the surface of the mild steel thereby forming a protective film.

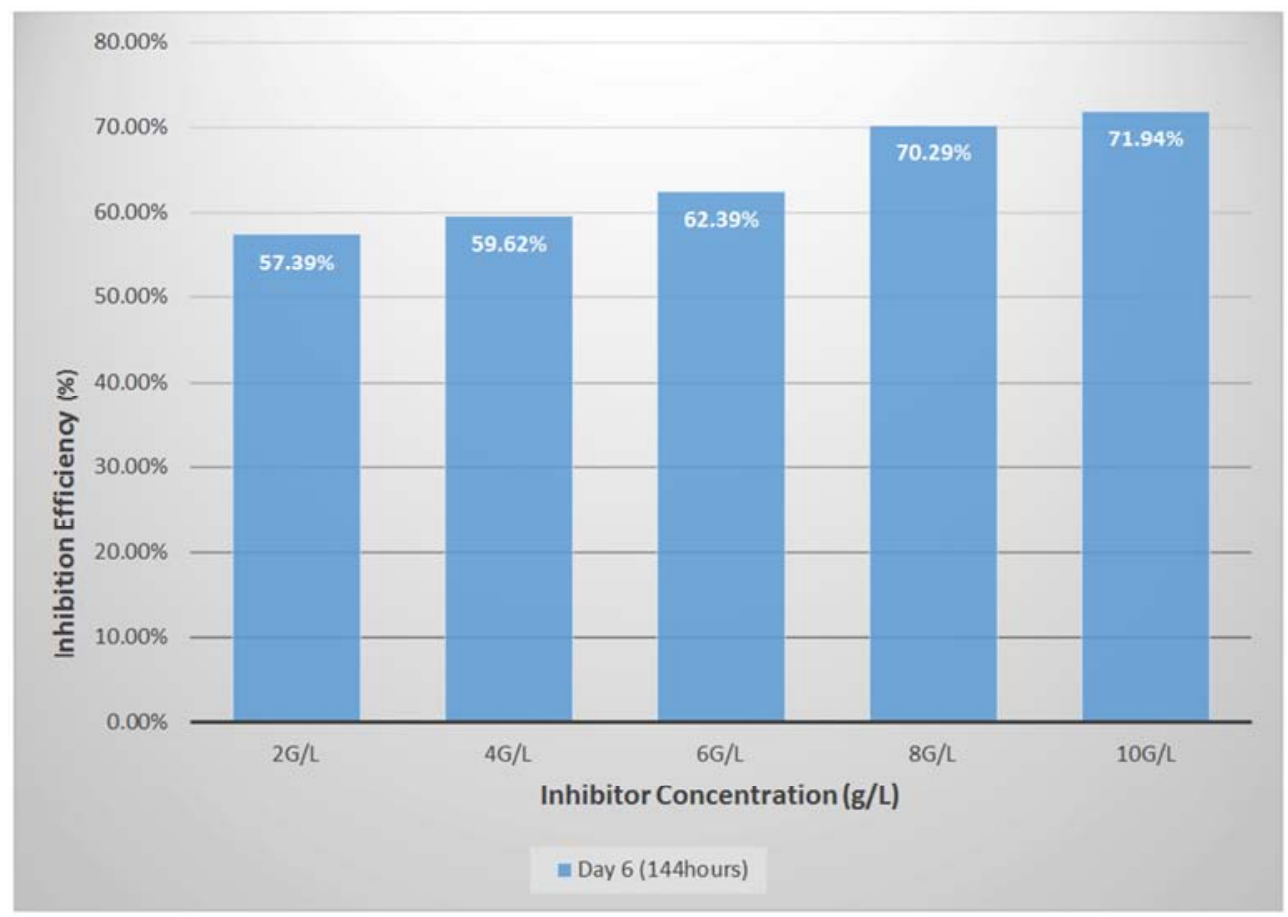

Figure 7. Chart showing variation of Inhibition Efficiency (\%) against Inhibitor Concentration $(\mathrm{g} / \mathrm{L})$ of Potassium Chromate (PC for Mild Steel in Seawater at the 6th day.

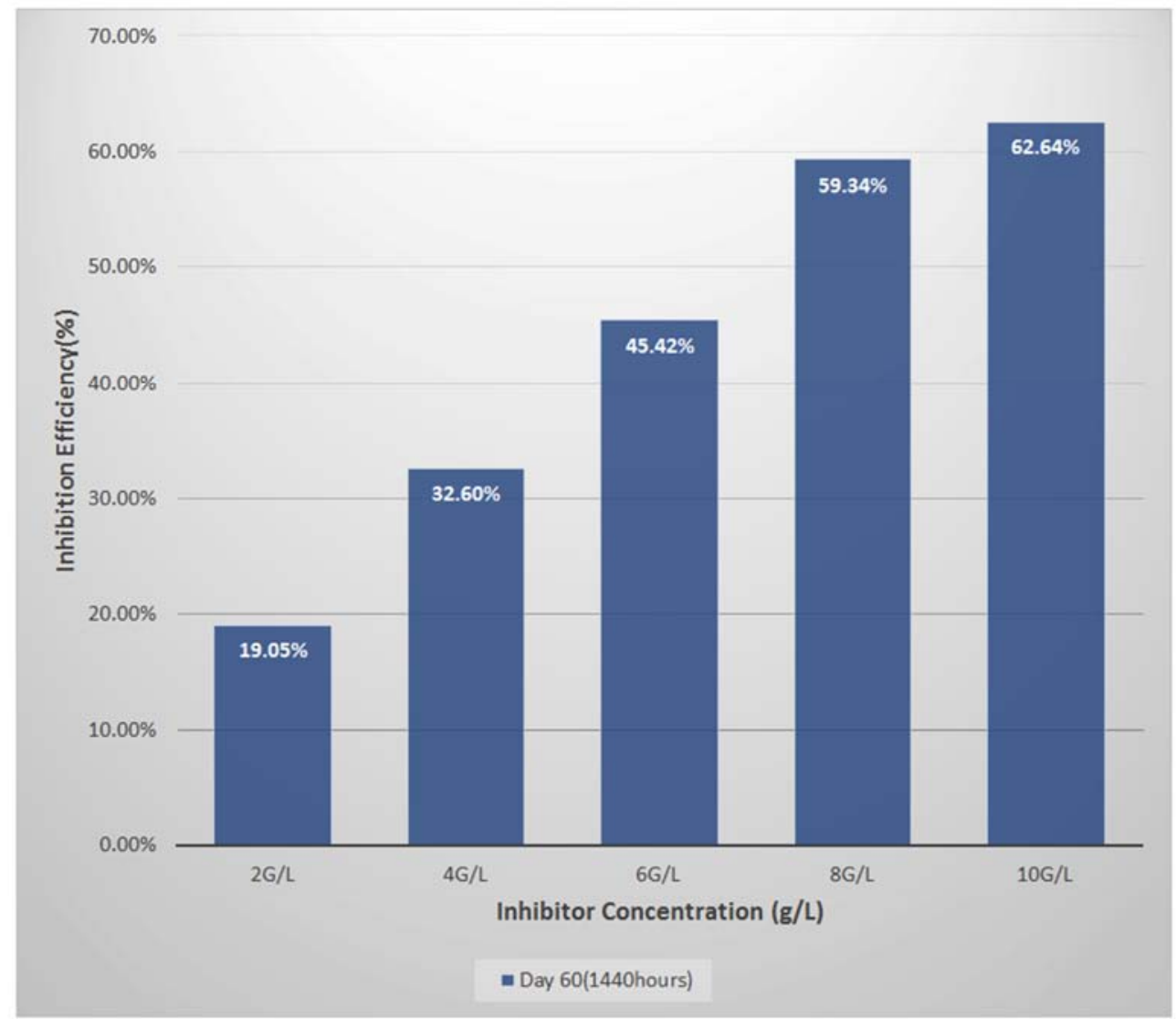

Figure 8. Chart showing variation of Inhibition Efficiency (\%) against Inhibitor Concentration ( $g / L)$ of Potassium Chromate (PC) for Mild Steel in Seawater at the 60th day. 


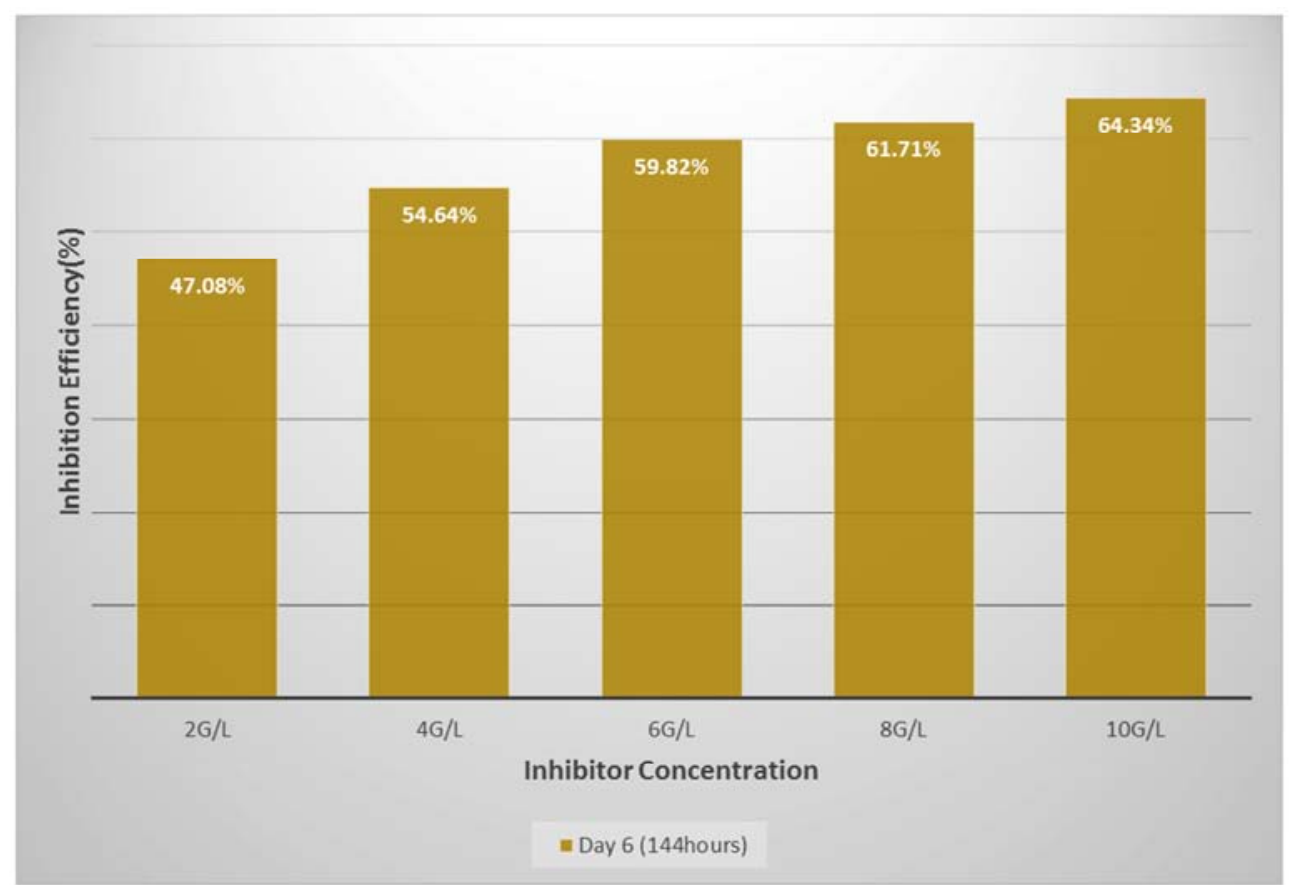

Figure 9. Chart showing variation of Inhibition Efficiency (\%) against Inhibitor Concentration ( $g / L)$ of Sodium Nitrite (SN) for Mild Steel in Seawater at the bth day.

Figure 9 show Inhibition efficiency of Sodium Nitrite (SN) inhibitor on the corrosion of mild steel in seawater at day 6 (144hours) with various Inhibitor concentrations.

There is a general progressive increase in inhibitor efficiency as the inhibitor concentration increases. The sodium nitrite inhibitor efficiency is lesser compared to the potassium chromate inhibition efficiency.

Another important observation from the chart is that at $2 \mathrm{~g} / \mathrm{L}$ inhibitor concentration, there is already a noticeable inhibition efficiency.

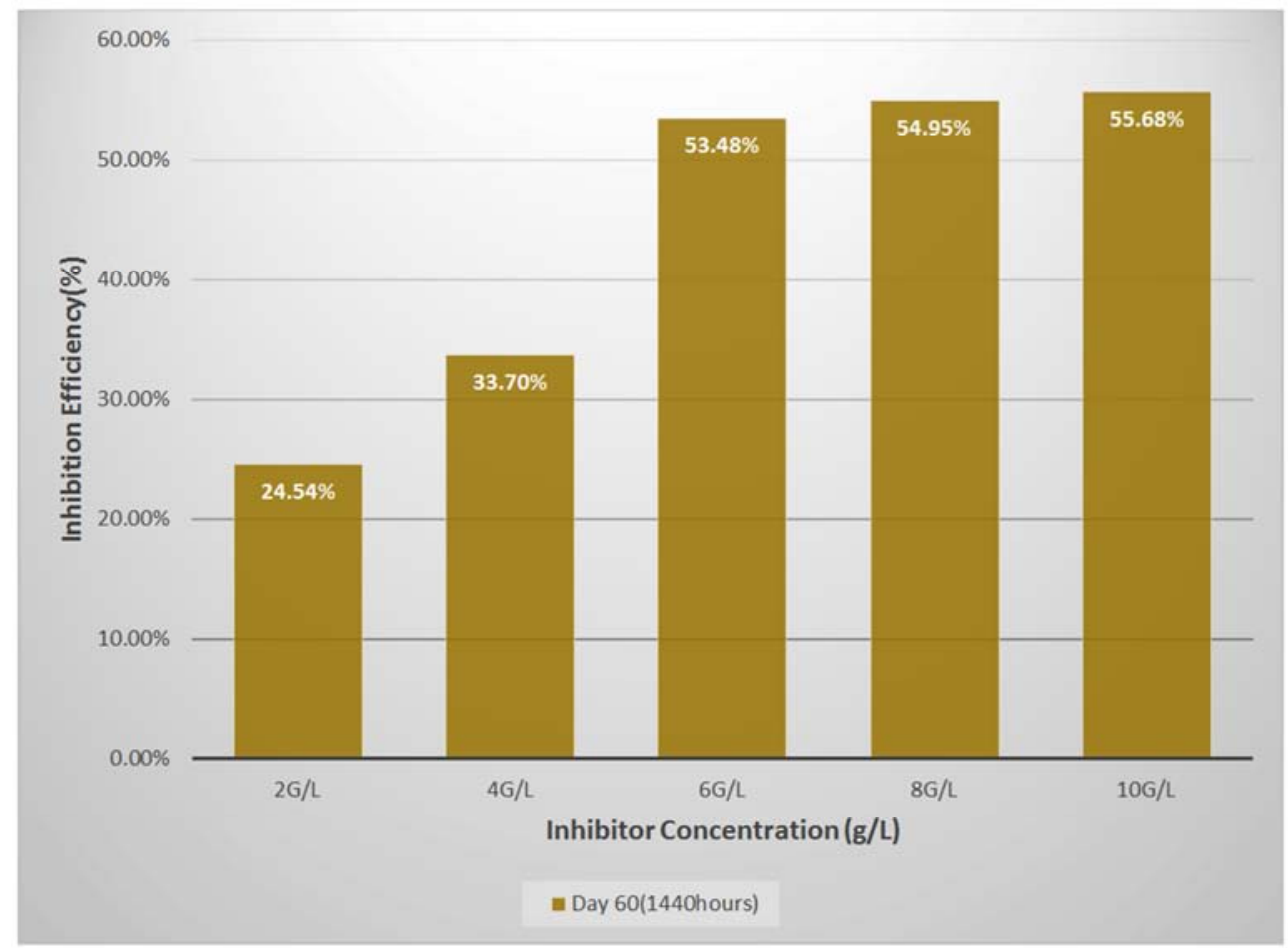

Figure 10. Chart showing variation of Inhibition Efficiency (\%) against Inhibitor Concentration (g/L) of Sodium Nitrite (SN) for Mild Steel in Seawater at the 60th day.

Figure 10 show Inhibition efficiency of Sodium Nitrite (SN) inhibitor on the corrosion of mild steel in seawater at day 60 (1440hours) with various Inhibitor concentrations.

There is a general progressive increase in inhibition 
efficiency as the inhibitor concentration increases. Observation at the 60th day demonstrates that sodium nitrite inhibitor shows a reduction in average inhibition efficiency of 447 percent compared to an average inhibition efficiency of 57.52 percent recorded for the sixth (6th) day.

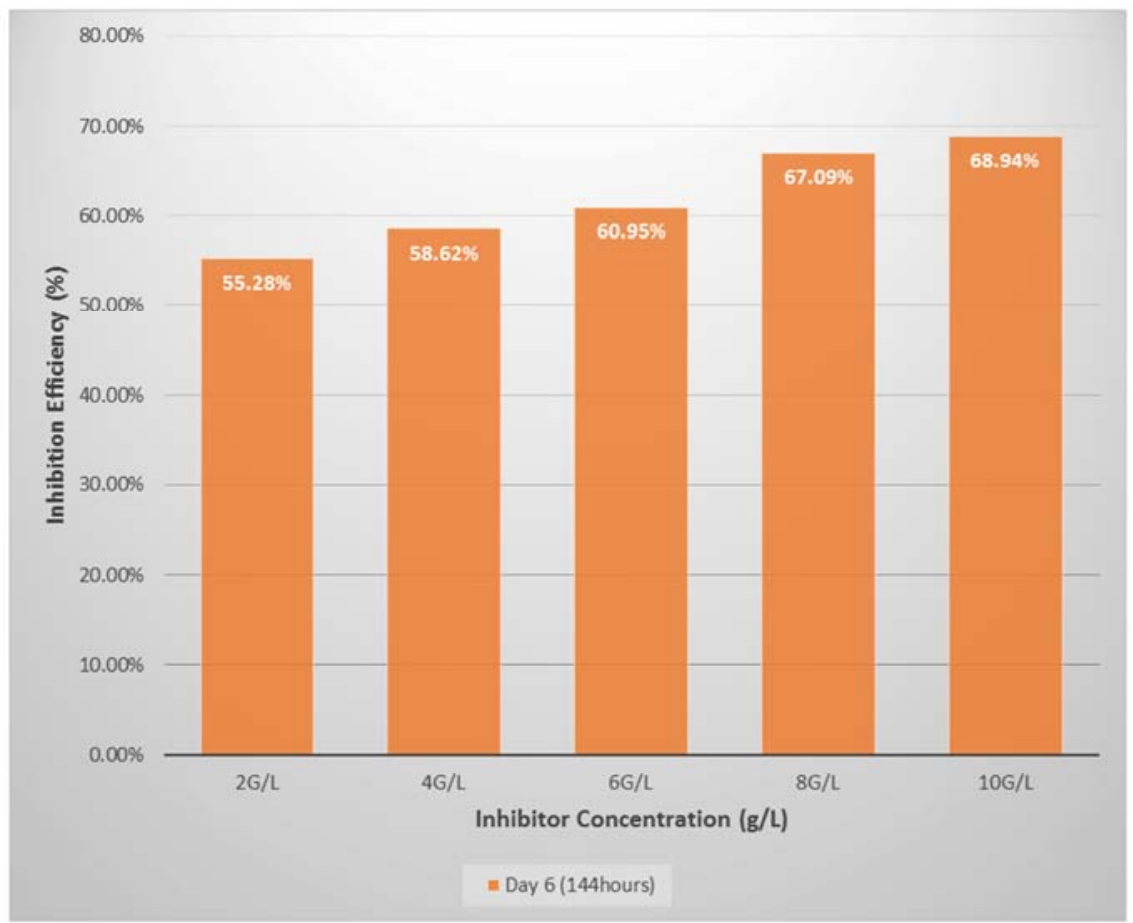

Figure 11. Chart showing variation of Inhibition Efficiency (\%) against Inhibitor Concentration ( $g / L)$ of Methyl Orange (MO) for Mild Steel in Seawater at the 6th day.

Figure 11 show Inhibition efficiency of Methyl Orange (MO) inhibitor on the corrosion of mild steel in seawater at day 6 (144 hours) with various inhibitor concentrations.

It is observed that the inhibition efficiency increases with increase in inhibitor concentration. The organic inhibitor, methyl orange is shown to exhibit higher inhibition efficiency than the inorganic inhibitors suggesting superior inhibitory properties.

The difference in inhibition efficiency of the $8 \mathrm{~g} / \mathrm{L}$ concentration and $10 \mathrm{~g} / \mathrm{L}$ concentration is minute.

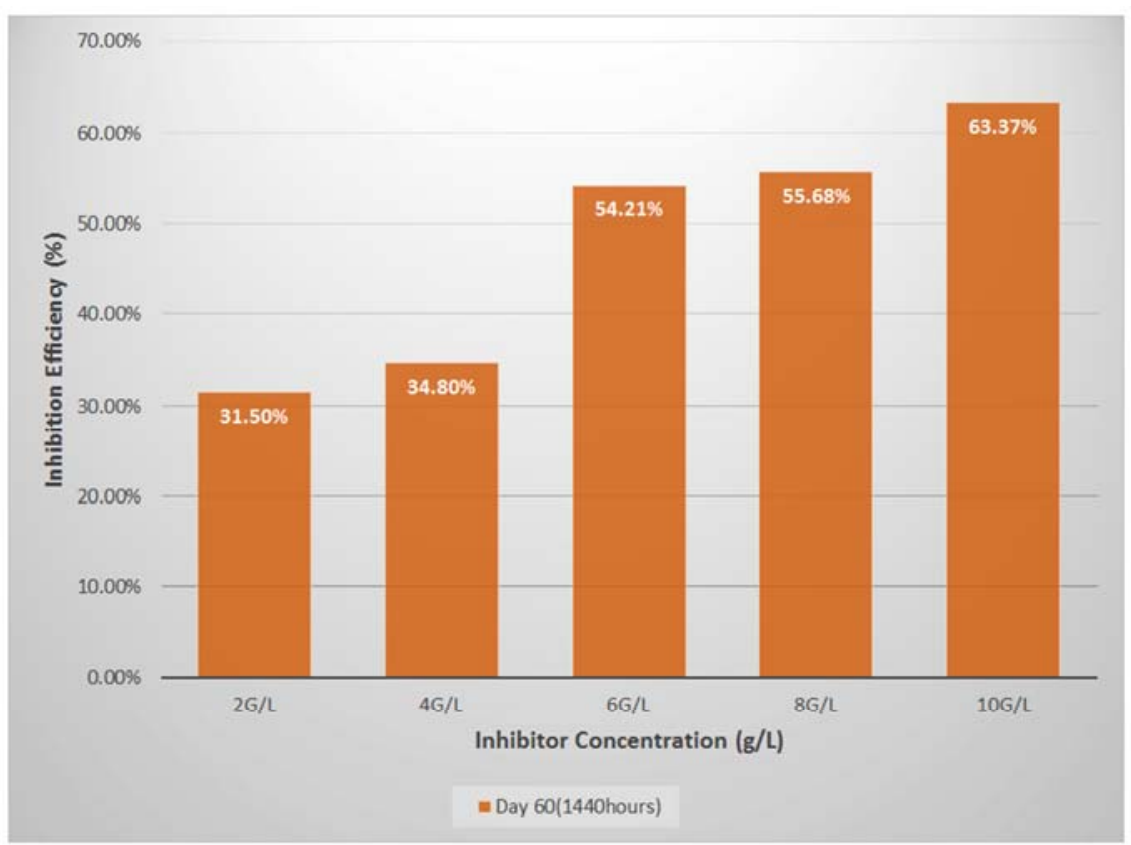

Figure 12. Chart showing variation of Inhibition Efficiency (\%) against Inhibitor Concentration (g/L) of Methyl Orange (MO) for Mild Steel in Seawater at the 60th day. 
Figure 12 show Inhibition efficiency of Methyl Orange (MO) inhibitor on the corrosion of mild steel in seawater at day 60 (1440 hours) with various inhibitor concentrations.

There is a general progressive increase in inhibition efficiency as the inhibition concentration increases. There is a decrease of inhibition efficiency at the 60th day.

Similarly, the organic inhibitor-methyl orange at day 60 exhibits a higher inhibition efficiency than the corresponding inorganic inhibitor of potassium chromate or sodium nitrite suggesting superior inhibitory properties.

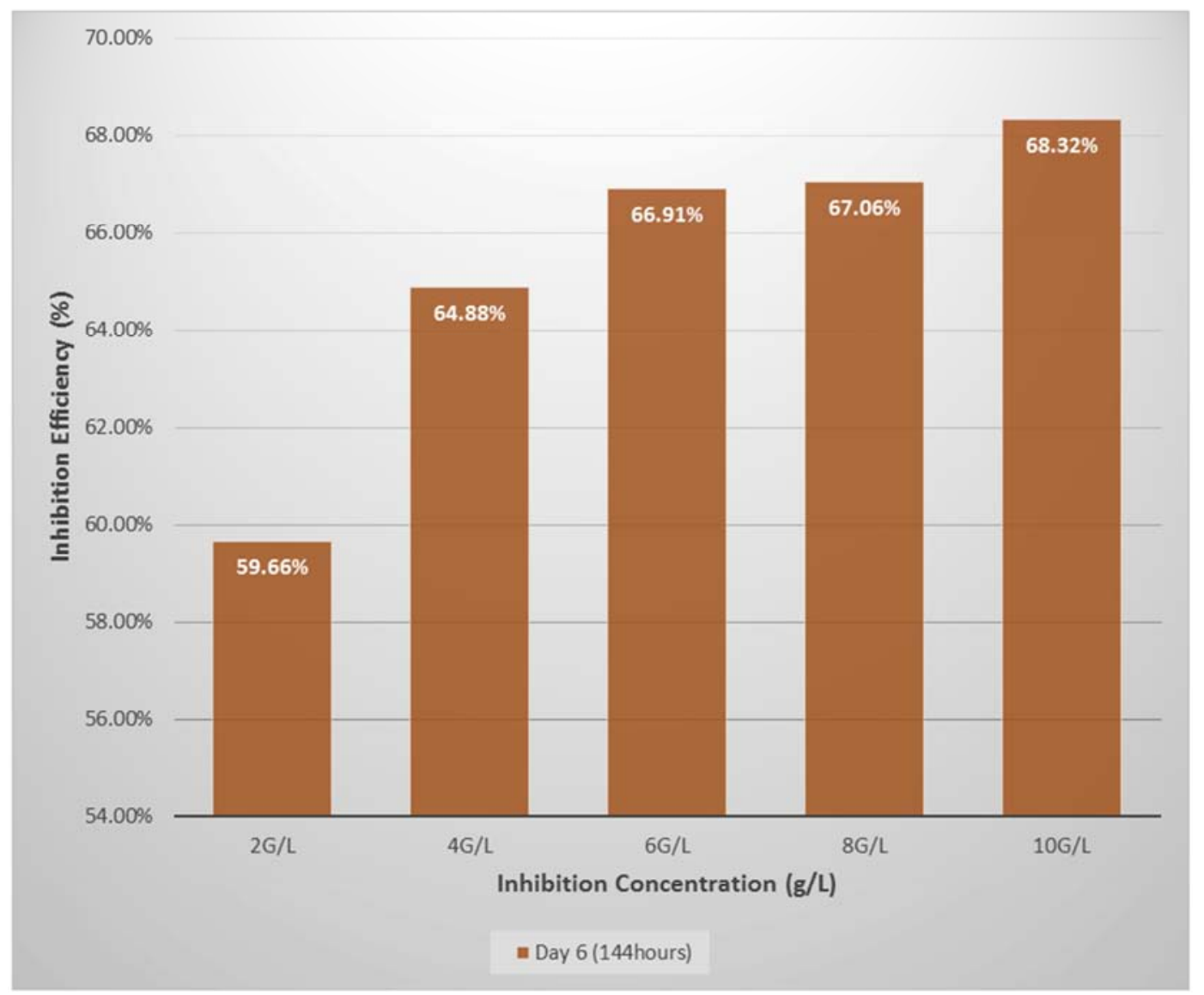

Figure 13. Chart showing variation of Inhibition Efficiency (\%) against Inhibitor Concentration ( $g / L)$ of Methyl Red (MR) for Mild Steel in Seawater at the 6th day.

Figure 13 show Inhibition efficiency of methyl red (MR) inhibitor on the corrosion of mild steel in seawater at day 6 (144 hours) with various inhibitor concentrations.

The trend from the chart reveals that there is a progressive increase in the inhibition efficiency with increase in inhibitor concentration.

At a concentration of $2 \mathrm{~g} / \mathrm{L}$, the methyl red inhibitor exhibits the highest inhibition efficiency. There is also higher inhibition efficiency at all inhibitor concentration in comparison to the inorganic inhibitors. This suggests that the organic inhibitor exhibits better inhibitory properties than the inorganic inhibitor of potassium chromate or sodium nitrite.

Figure 14 show Inhibition efficiency of methyl red (MR) inhibitor on the corrosion of mild steel in seawater at day 60 (1440 hours) with various inhibitor concentrations.

There is a decrease in inhibition efficiency across immersion time from day 6 to day 60 .

The chart trend reveals that there is increase in inhibition efficiency as the inhibition concentration increase from $2 \mathrm{~g} / \mathrm{L}$ to $8 \mathrm{~g} / \mathrm{L}$. At day 60 , the inhibitor efficiency is highest for the methyl red at the inhibitor concentration of $8 \mathrm{~g} / \mathrm{L}$.

Figure 15 show Inhibition efficiency of Terminalia Catappa Leaves (CPL) extract inhibitor on the corrosion of mild steel in seawater at day 6 (144 hours) with various inhibitor concentrations.

There is a general progressive increase in the inhibition efficiency with increase in inhibitor concentration. At the 6th day, the average inhibition efficiency for the Terminalia Catappa leaves extract inhibitor is 59.4 percent. This suggests an improved inhibition efficiency compared to sodium nitrite inhibitor.

Figure 16 show Inhibition efficiency of Terminalia Catappa Leaves (CPL) extract inhibitor on the corrosion of mild steel in seawater at day 60 (1440hours) with various inhibitor concentrations.

From the chart trend, it is observed that there is a general progressive increase in the inhibition efficiency with increase in inhibitor concentration. There is also a decrease in inhibition efficiency through immersion time from day 6 to day 60 . 


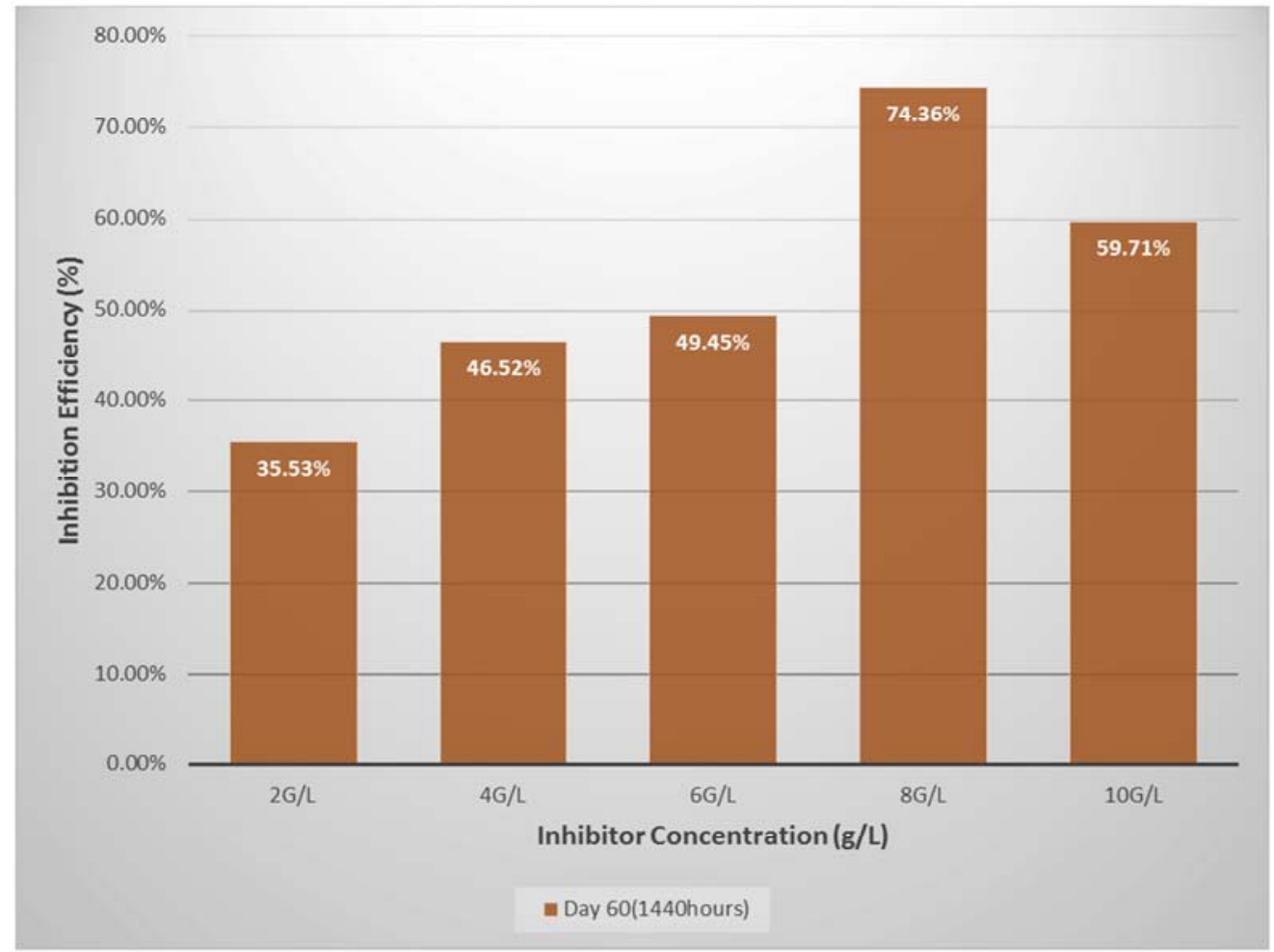

Figure 14. Chart showing variation of Inhibition Efficiency (\%) against Inhibitor Concentration ( $g / L$ ) of Methyl Red (MR) for Mild Steel in Seawater at the 60th day.

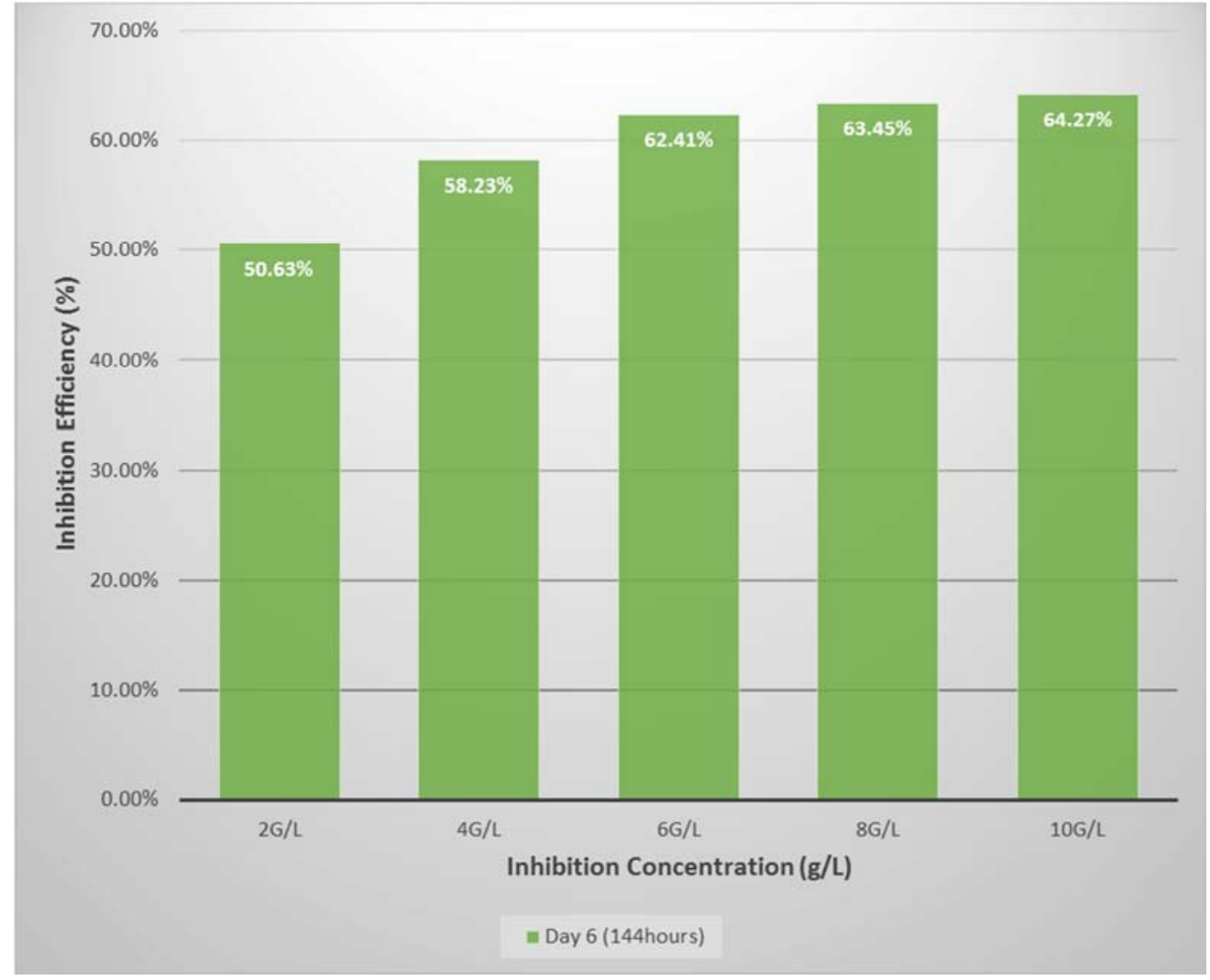

Figure 15. Chart showing variation of Inhibition Efficiency (\%) against Inhibitor Concentration (g/L) of Terminalia Catappa Leaves (TCL) Extract for Mild Steel in Seawater at the 6th day. 


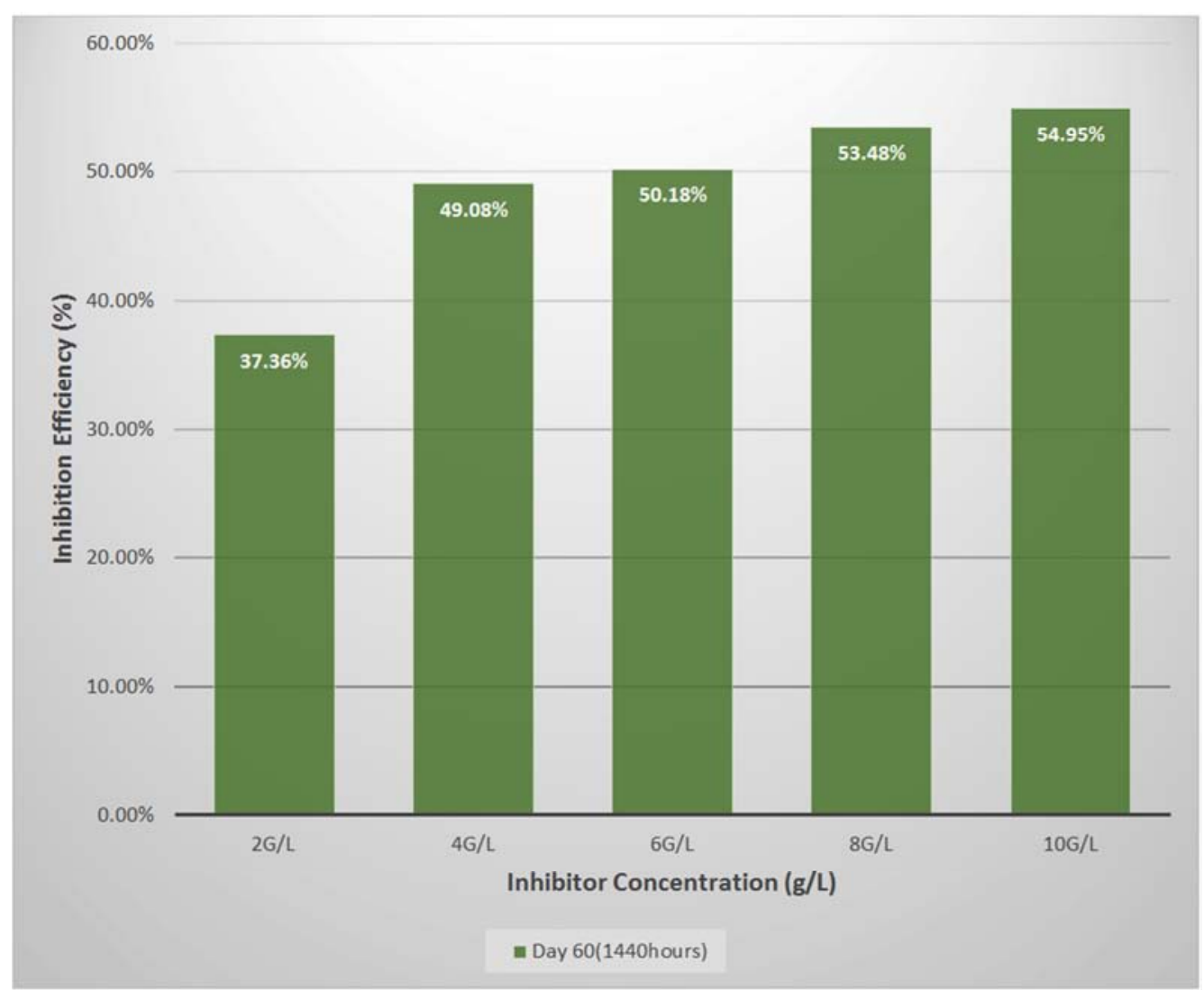

Figure 16. Chart showing variation of Inhibition Efficiency (\%) against Inhibitor Concentration $(g / L)$ of Terminalia Catappa Leaves (TCL) Extract for Mild Steel in Seawater at the 60th day.

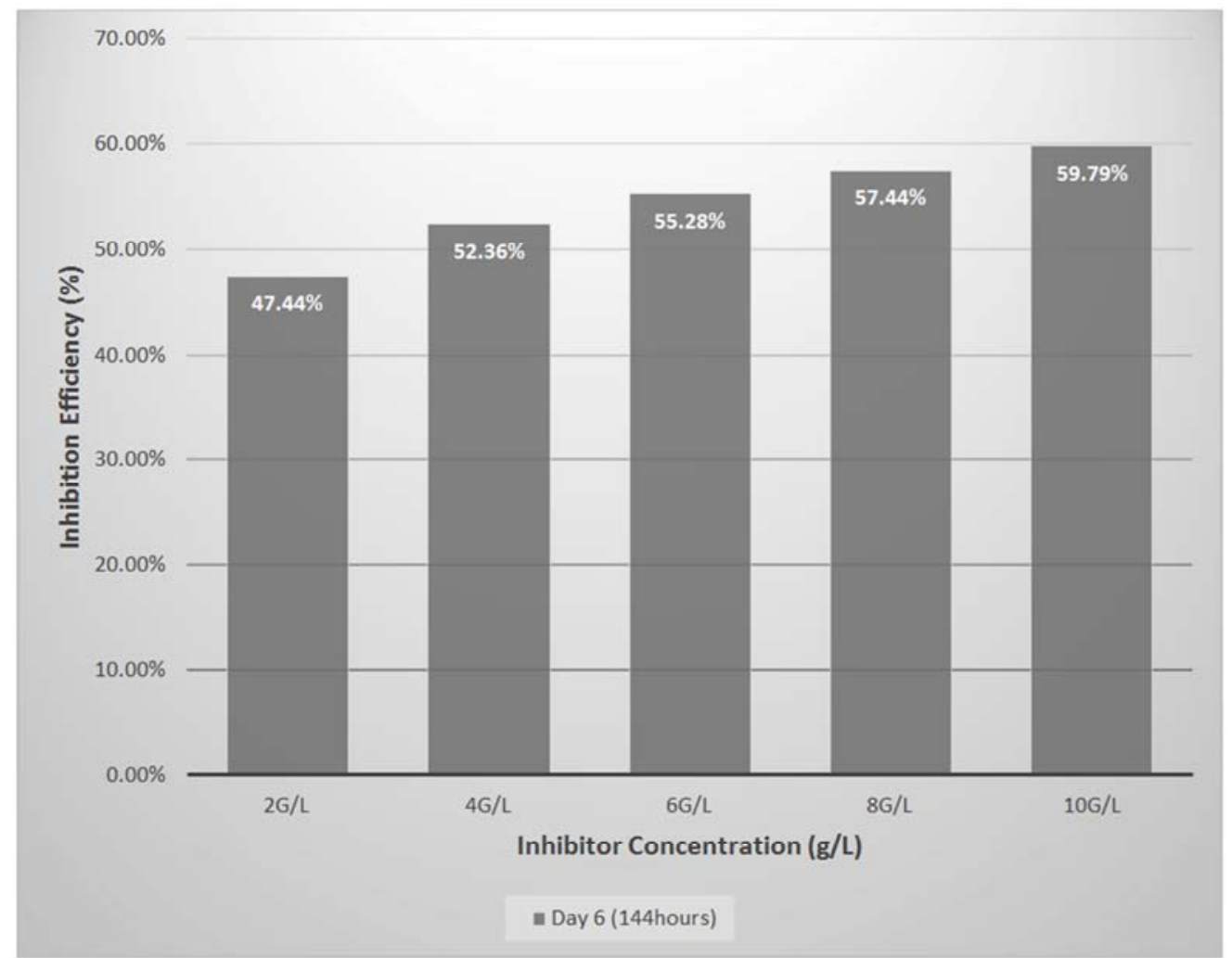

Figure 17. Chart showing variation of Inhibition Efficiency (\%) against Inhibitor Concentration $(g / L)$ of Carica Papaya leaves (CPL) Extract for Mild Steel in Seawater at the 6th day. 
Figure 17 show Inhibition efficiency of Carica Papaya Leaves (CPL) extract inhibitor on the corrosion of mild steel in seawater at day 6 (144 hours) with various inhibitor concentrations.

There is a general progressive increase in the inhibition efficiency with increase in inhibitor concentration. At the 6th day, the average inhibition efficiency for the Carica papaya leaves extract inhibitor is 55 percent. This suggests a little above average performance and hence the lowest inhibition efficiency displayed among the corrosion inhibitors.

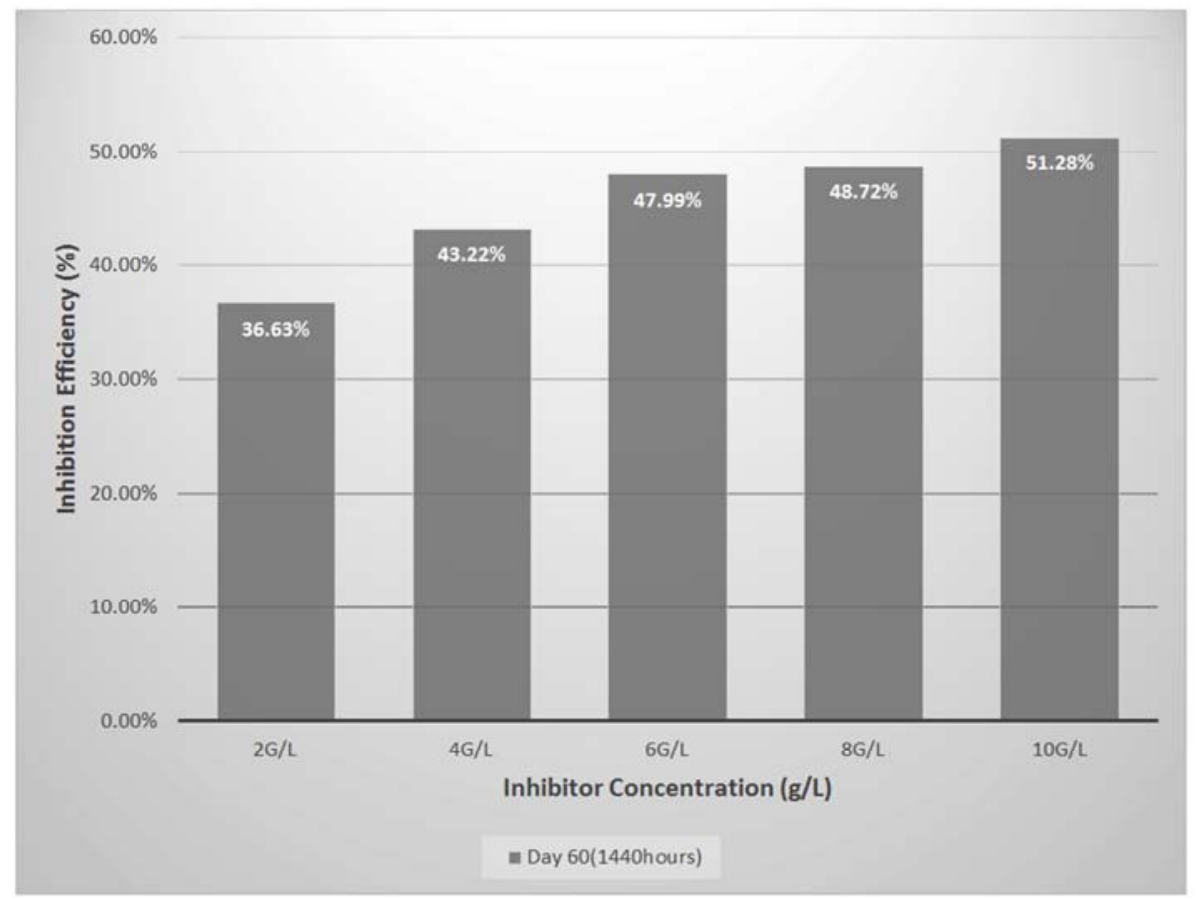

Figure 18. Chart showing variation of Inhibition Efficiency (\%) against Inhibitor Concentration ( $g / L)$ of Carica Papaya leaves (CPL) Extract for Mild Steel in Seawater at the 60th day.

Figure 18 show Inhibition efficiency of Carica Papaya Leaves (CPL) extract inhibitor on the corrosion of mild steel in seawater at day 60 (1440 hours) with various inhibitor concentrations.

There is a general progressive increase in the inhibition efficiency with increase in inhibitor concentration. The inhibition efficiency decrease across immersion time from the 6 th day to the 60 th day.

\subsection{Discussion}

\subsubsection{The Effect of Inhibitors' Concentrations and Immersion Time on the Corrosion Rate of AISI 1019 Steel in Seawater Environment}

Results presented in Table 3 showed the corrosion rate of mild steel in seawater in the presence of varying concentration of selected inhibitors for a 60 days' immersion period.

It shows that the corrosion rate of the control solution (solution without inhibitor) increases linearly with immersion time as seen in Figure 1 to Figure 6, indicating that seawater is highly corrosive under studied conditions. These results are in agreement with previous studies on the corrosion of carbon steel in the Red Sea carried out by Aisha [2].

Looking through the plot presented in Figure 1, the corrosion rate decreases with increasing Inhibitor concentration level while the corrosion rate increases as the period of immersion increases. It is a general trend that the aggressiveness of the sea water reduces with increase in the inhibitor concentration level. This is also depicted clearly in Figure 2 to Figure 6.

As shown in the Figures, the inhibitors do not stop corrosion but delays the onset of corrosion thereby leading to decrease in the corrosion rate. Comparing the graphs in the figures, it could be seen clearly that the corrosion rates for the uninhibited corrosive medium (control solution) is very high and lowest in the medium with $10 \mathrm{~g} / \mathrm{L}$ inhibitor concentration. These findings are in agreement with studies made on the effect of sodium nitrite on the inhibition of carbon steel in seawater investigated using the weight loss method [3].

The reason for this phenomenon can be attributed to the protective film formed by the inhibitor on the metal surface which is broken by the aggressive chloride ions present in the sea water and the corrosion rate increases as the experiment progresses until there is formation of corrosion product. This corrosion product formed is not strictly passivating as it acts as a film, especially in the presence of aggressive ions such as the chloride ions. If the chloride ions are present in the aqueous phase, it can penetrate the corrosion product layer and corrode the steel although at reduced rate due to the presence of the corrosion inhibitor [6].

It takes a much longer time to reach a steady state which is 
not seen in this study because the immersion period included in the study are not sufficient to reach steady state.

\subsubsection{The Effect of Inhibitors' Concentrations and Immersion Time on the Inhibition Efficiency AISI 1019 Steel in Seawater Environment}

Table 4 show the inhibition efficiency of mild steel in seawater in the presence of varying inhibitor concentration and immersion time.

A general trend of increasing inhibition efficiency with increase in inhibitor concentration and decreasing inhibition efficiency with increase in immersion period was observed in the plots of Figure 7 to Figure 18. These findings are in agreement with the works of Selvaraj [10]. Carbon steel specimens in triplicate were immersed in $100 \mathrm{ml}$ of the seawater solutions containing various concentrations of the inhibitor in the presence and absence of $\mathrm{Zn}^{2+}$ for one day.

These results were further authenticated by Omotosho [7] whose work researched on the inhibition evaluation of chemical and plant extract on the corrosion of metallic alloys in acidic environment. He found out that the inhibition efficiency decreased with immersion time and increased with increase in inhibitor concentration.

According to Ijeoma [5] the reduction in inhibitor efficiency with time may be attributed to the inhibitor reacting with a component of the system leading to loss of inhibitor or getting depleted/used-up with time due to the chemical reactions occurring within the system. Thus, there could be reduction in inhibition efficiency with immersion time due to desorption.

It is worthy to note that the potassium chromate inhibitor exhibits a better inhibition efficiency than the counterpart inorganic inhibitor of sodium nitrite. This claim is validated by the works of Afolabi [1] whose work investigated the corrosion inhibition of mild steel in $3.5 \mathrm{M}$ sodium chloride and $0.3 \mathrm{M}$ sodium sulphide media using varied concentrations of potassium chromate and sodium nitrite. This could be attributed to cathodic and anodic inhibitive effects produced by the chromate ions as compared to only anodic inhibition in nitrite ions.

Also of peculiar interest is the trend at the beginning of the experiment, the organic inhibitor showed a superior inhibition efficiency than the inorganic and green inhibitor counterparts. This is suggesting that the organic inhibitors possess better inhibitory properties than the inorganic inhibitors. This is in agreement with the work of Vishnudevan [11] who carried at a comparative study of Organic versus inorganic inhibitors for mitigation of steel in chloride contaminated alkaline solution.

\section{Conclusion and Recommendation}

Having investigated the effect of different corrosion inhibitors on the corrosion behaviour of $0.19 \% \mathrm{c}$ steel in seawater environment. There is a reason to believe that varying the inhibitor concentration at various immersion time has effect on the inhibitor efficiency of $0.19 \% \mathrm{C}$ steel. The inorganic inhibitor (potassium chromate) had its highest inhibition efficiency of $71.94 \%$ at a concentration of $10 \mathrm{~g} / \mathrm{L}$, the inorganic inhibitor (Sodium Nitrite) had the its Inhibition efficiency of $64.34 \%$ at a concentration of $10 \mathrm{~g} / \mathrm{L}$ while The Organic Inhibitor (Methyl Orange) had the highest Inhibition Efficiency of $68.94 \%$ at a concentration of $10 \mathrm{~g} / \mathrm{L}$.

\section{References}

[1] Afolabi, A. S., 2007. Synergistic Inhibition of Potassium Chromate and Sodium Nitrite on Mild Steel in Chloride and Sulphide Media. Leornado Electronic Journal of Practices and Technology (LEJPT) Academic direct, pp. 145-153.

[2] Aisha, H., Al-Moubarak, Awatif, A.-J. and Maryam, A., 2015. Corrosion of C-Steel in the Red Sea: Effect of Immersion Time and Inhibition Concentration. International Journal of Electrochemical Science, 1 (10), pp. 4252-4278.

[3] Aramide, O. F., 2009. Corrosion Inhibition of AISI/SAE Steel in a Marine Environment. Leonardo Journal of Sciences, I (15), pp. 47-52.

[4] Fontana, M. G., 1987. Corrosion Engineering. New York: McGraw-Hill.

[5] Ijeoma, M. N. C., 1991. "Elements of Corrosion and Protection Theory". 2nd ed. Enugu: Auto century publication company limited.

[6] Lujia, Yang., Yunze, Xu., Yesen, Zhu., Liang, Liu., Xiaona, Wang., and Yi Huang 2016. Evaluation of Interaction Effect of Sulfate and Chloride Ions on Reinforcements in Simulated Marine Environment Using Electrochemical Methods. International Journal of Electrochemical Science, XI (1), pp. 6943-6958.

[7] Omotosho, O. A., 2016. Inhibition Evaluation of Chemical and Plant Extracts on the Corrosion of Metallic Alloys in Acidic Environment. PH. D Thesis of mechanical Engineering, 10 May. pp. 1-214.

[8] Onyekpe, B. O., 2002. Corrosion in Oil and Gas Production. Benin city: Ambik press.

[9] Poopola, L T., Grema, A S., Latinwo, G K., Gutti, B., Balogun, A S., 2013. Corrosion Problems During Oil and Gas Production and its Mitigation. International Journal of Industrial Chemistry, IV (36), pp. 1-15.

[10] Selvaraj, S. K., Amalraj, J. A., Dharmalingam, V. and sahayaraj, W. J., 2016. Synergistic Corrosion Inhibition Effect Of Carbon Steel in Seawater by Propyl Phosphonic Acid $\mathrm{Zn} 2+$. International Journal of Nano Corrosion Science and Engineering, April, 3 (1), pp. 79-95.

[11] Vishnudevan, M. and Thangavel, K., 2007. A comparative study of Organic versus inorganic inhibitors for mitigation of steel in chloride contaminated alkaline solution. Indian Journal of Chemical Technology, XIV (14), pp. 22-28. 